\title{
JUVENTUD Y PEDAGOGÍA (SOBRE LA GÉNESIS DEL PENSAMIENTO DE WALTER BENJAMIN)
}

\author{
Youth and pedagogy (On the genesis of the thought \\ of Walter Benjamin)
}

\author{
Jeunesse et pédagogie (À propos de la genèse \\ de la pensée de Walter Benjamin)
}

\author{
Lluís Ballester Brage* y Antoni J. Colom Cañellas** \\ Universitat de les IIles Balears. Facultad de Educación. Campus Universitario. \\ Ctra. de Valldemossa, km 7,6.07122 Palma. Correo-e: "lluis.Ballester@uib.es, \\ antoni.colom@uib.eu
}

Fecha de recepción: enero de 2011

Fecha de aceptación definitiva: abril de 2011

Biblid [(1130-3743) 23, 1-2011, 71-106]

\section{RESUMEN}

Los autores analizan los 16 escritos de juventud -que escribió entre los 19 y los 23 años- de W. Benjamin, referidos todos ellos a cuestiones de carácter educativo, y en donde se demuestra la influencia decisiva de G. Wyneken. También se estudian los temas que el joven W. B. abordó, a saber: idealismo y cultura juvenil, la necesidad de las reformas escolares y universitarias, la educación moral, estética y religiosa, así como la sexualidad juvenil. Sin embargo, lo más importante es que en estos trabajos se encuentran las constantes que caracterizarán el resto de su obra, tales como su individualismo, su obsesión por su propia biografía infantil, sus contradicciones y tránsitos temáticos, su interés por la estética y el arte, la complejidad de su obra, su agnosticismo y la consideración del judaísmo como elemento cultural y, sobre todo, ya se descubre su sentido crítico y su vocación por la crítica. De alguna forma en estos artículos de temática educativa se descubren muchas de las constantes de lo que será la obra posterior de este autor. 
Palabras clave: Walter Benjamin y la educación, W. Benjamin y la juventud, orígenes del pensamiento de W. Benjamin, W. Benjamin y G. Wyneken.

\section{SUMMARY}

The authors analyze the 16 early writings that $\mathrm{W}$. Benjamin wrote between the ages of 19 and 23, all of which relate to educative matters, and where the decisive influence of G. Wyneken is shown. The issues that the young Walter Benjamin addresses are also studied, such as idealism and youth culture, the necessity of reform in schools and universities and also in moral, aesthetic and religious education as well as in juvenile sexuality. However, the most important thing is that in these works one can find the constants that characterize the rest of his production, such as his individualism, his obsession with his own childhood experiences, his contradictions and thematic transitions, his interest in aesthetics and art, the complexity of his work, his agnosticism and his consideration of Judaism as a cultural element, and above all his critical sense and his vocation for criticism which starts to become evident. Somehow in these articles of educative content one can discover many of the constants of what will be the subsequent work of this author.

Key words: Walter Benjamin and education, W. Benjamin and youth, the origins of the thought of W. Benjamin, W. Benjamin and G. Wyneken.

\section{SOMMAIRE}

Les auteurs analysent les 16 écrits de jeunesse que Benjamin a rédigé entre 19 et 23 ans, rapportés tous à des questions de thème éducatif et très indicatifs de l'influence de G. Wyneken. On étudie aussi les sujets que le jeune W. B. a abordé: l'idéalisme et la culture juvénile, la nécessité des réformes scolaires et universitaires, l'éducation morale, esthétique et religieuse, ainsi que la sexualité juvénile. Cependant, le plus important est que, parmi ces travaux, il y a des sujets qui son constants et que vont caractériser le reste de son oeuvre, tel que, son individualisme, son obsession par sa propre biographie infantile, ses contradictions et changements thématiques, son intérêt à l'esthétique et à l'art, à la complexité de son oeuvre, son agnosticisme et la considération du judaïsme comme élément culturel, et surtout, déjà son sens critique et sa vocation par la critique.

Dans ces articles on peut y découvrir plusieurs tendences que vont devenir constantes dans l'oeuvre postérieure de cet auteur.

Mots clés: Walter Benjamin et l'éducation, W. Benjamin et la jeunesse, des origines de la pensée de W. Benjamin, W. Benjamin et G. Wyneken. 
En pocas ocasiones puede encontrarse una obra como la de Walter Benjamin (Berlín, 1892-Port Bou, 1940) ${ }^{1}$, que sirva tan claramente para especificar cómo se constituye el pensamiento de un autor, en este caso desde la dialéctica hegeliana a la marxista. Sin embargo -independientemente de otras características de sus escritos tales como su extensión ${ }^{2}$, su atomismo, su variedad temática, su complejidad, a veces su simbolismo y también, por qué no decirlo, su esnobismo y diletantismo, entre otros aspectos-, su obra se ha resistido a un análisis si no coherente, sí al menos unitario y holístico; sin duda antes que global, la bibliografía sobre Walter Benjamin ha sido fundamentalmente de carácter temático y específico.

Quizás por ello, la literatura que ha generado no ha considerado con la atención debida unos escasos artículos de juventud, que si bien pueden tacharse de marginales en relación a sus innumerables escritos ${ }^{3}$, sin embargo, si se leen atentamente, nos pueden aportar claves interesantes para intuir su futura trayectoria y para, por supuesto, evidenciar la convergencia que se da entre su biografía real y sus escritos. También puede suceder que la falta de atención que han merecido estos artículos se deba al hecho de tratar cuestiones pedagógicas, lo que asimismo nos puede llevar a considerar el porqué de tal olvido, a saber, sus estudiosos han obviado en sus trabajos sobre Benjamin estas aportaciones por considerarlas como mínimo secundarias y acaso propias de un "pensamiento débil", en comparación con sus aportaciones sociofilosóficas; en cambio, los pedagogos han obviado al autor, simplemente por no considerarlo.

1. Se llamaba Walter Bendix Schönflies Benjamin y sus fechas concretas de nacimiento y fallecimiento son 15 de julio de 1892 y la madrugada del 26 de septiembre de 1940. No debe extrañarnos entonces que su amigo Gershom Scholem -se conocieron en 1915 y siempre se mantuvieron en contacto a pesar de que Gershom se instalase en Jerusalén- escribiese un libro en el que se refiere a sus nombres secundarios, en relación a la costumbre judía de aportar un nombre secreto para la celebración de la pubertad; véase Scholem (2004).

2. La obra de W. Benjamin se nos aparenta de unas dimensiones dignas de tenerse en cuenta, máxime si recordamos sus 48 años de vida, entre ellos sus siete años de exilio con la dificultad que le conllevó acceder a su biblioteca, además de sus múltiples viajes, su azarosa biografía, sus problemas económicos y otras múltiples preocupaciones -la separación de su esposa Dora Kellner en 1930 hizo que tuviese que hipotecar toda la herencia de su familia-, sus amores siempre fallidos o su primer intento de suicidio en Niza (julio de 1932), etc. Sus escritos están recogidos en sus Geseammelte Schriften, en 12 volúmenes integrados en 6 tomos. Editados por Surhrkamp Verlag, Fráncfort, entre 1972-1985 (nueva edición en 1989); con esta misma composición la editorial Abada de Madrid viene publicando su obra desde 2006. También cabe citar la edición de sus Selected Writings, en cuatro tomos, según versión de Marcus Bullock y Michael W. Jennings, y editados por la Harvard University press, Cambridge (Mass.), entre 1996 y 2002.

3. Queremos advertir desde un principio que este trabajo sólo se referirá a los escritos de juventud de W. Benjamin, tal como se expresa en el título del mismo. Por razones de espacio expondremos sucintamente la aportación que nuestro autor realizó en estos escritos, dejando en consecuencia para otra ocasión el proyecto de análisis de toda su obra pedagógica, en la que seguimos trabajando. 


\section{Contexto}

Walter Benjamin, a lo largo de su obra, manifestó en más de una ocasión interés por la cuestión educativa, al menos por una razón, y es porque sus etapas educativas lo marcaron de forma muy significativa en su devenir vital, de tal manera que pedagogía y vida se evidencian en él de forma insoslayable ${ }^{4}$. Su interés por la infancia ${ }^{5}$, la recreación que de ella hace en alguna de sus obras ${ }^{6}$, su colección de juguetes y libros infantiles ${ }^{7}$, sus emisiones radiofónicas dedicadas a los niños ${ }^{8}$, entre otras actividades y escritos ${ }^{9}$, nos muestran un sustrato pedagógico que de todas formas, a pesar de que siga siendo minoritario, no por ello deja de ser interesante, máxime cuando reflejan acertadamente muchos aspectos decisivos de su biografía y de su bibliografía.

Puede decirse que W. Benjamin inicia su aventura publicista a través de sus artículos pedagógicos ${ }^{10}$; se trata de 16 trabajos de longitud muy variable y que fue sacando a la luz, muchos bajo seudónimo, entre 1911 y 1915 en diversas revistas y otras publicaciones ${ }^{11}$, es decir, entre sus 19 y 23 años. Sin duda,

4. Una aproximación a esta tesis puede encontrarse en la reciente obra de STEWART (2010).

5. Véase Benjamin (1987a, nueva edición en 1992). En francés y bajo el título Enfance berlinoise, publicado por Lettres Nouvelles/Maurice Nadeau, en París, 1978, e integrado en el libro titulado: Sens unique, con estudio de J. Lacoste. A mayor abundamiento cabe decir que este texto fue iniciado y preparado en Ibiza, en la primavera de 1932, cuando residió en ella por primera vez. Para esta cuestión véase, por ejemplo, VALERo (2008).

6. Uno de sus textos más conocidos, "El Narrador", escrito en 1936, se dice que está inspirado por el recuerdo de su madre cuando ésta, siendo él niño, le narraba cuentos antes de dormirse: vid. Stewart, op. cit. Puede encontrarse este texto en Benjamin (1991b). Por nuestra parte consideramos que es más un estudio a propósito de la obra de Leskov. De este autor véase Leskov (2003).

7. El 23 de junio de 1932 escribe a R. Weissbach desde San Antonio de Ibiza lo siguiente: "...yo he reunido una de las colecciones más importantes de los libros infantiles alemanes...". Vid. p. 61 de Benjamin (2008). De todas formas juguetes y libros infantiles conforman una constante en sus escritos, cualquiera que sea su índole.

8. Escribió más de ochenta guiones radiofónicos, muchos de ellos dedicados a los niños, que se retransmitían bien desde Berlín, bien desde Fráncfort. Fruto de tal experiencia es su escrito: "Teatro y radio. Sobre el control recíproco de lo que es su trabajo educativo". Vid. Benjamin, Obras (2009, libro II, vol. 2, 389-393).

9. Véase su "Program for a Proletarian Children's Theater", en Benjamin (1999a, 202-205).

10. Parece ser no obstante que su primer trabajo publicado corresponde a 1910, y lo hizo en la revista Der Anfang (El comienzo). Véase Tiedemann, GödDe y Lonitz (1990).

11. Estos artículos a los que nos referimos y en los que nos basaremos son los siguientes: 1. "La bella durmiente", publicado en Der Anfang (1911), bajo el seudónimo de Ardor, pp. 9-16; 2. "La reforma escolar, un movimiento cultural" (1912), bajo seudónimo de Eckhart, en Studentenschaft, órgano de la Asociación de estudiantes libres - "Freie Studentensschaft- de la Universidad de Friburgo, pp. 13-16; 3. "Diálogo sobre la religiosidad del presente", artículo no publicado -sólo en sus Obras completas-, y escrito muy posiblemente entre finales de 1912 y principios de 1913, pp. 16-35; 4. ${ }^{\circ}$ "Enseñanza y valoración" (1913), bajo el seudónimo de Ardor, publicado en los números de mayo y junio de la revista juvenil Der Anfang, pp. 35-42;.$^{\circ}$ "Romanticismo. Un discurso no pronunciado ante 
y como evidenciaremos, casi todos ellos tienen su origen en su propia biografía como colegial, tanto en sus años de enseñanza secundaria como universitaria ${ }^{12}$. Ahora bien, tal afirmación no significa que sus escritos sean fiel reflejo de su vida escolar, como pudiera ser por ejemplo un diario, o notas sobre sus recuerdos de aquella época; al contrario, se trata de trabajos de alto contenido cultural e ideológico, en los que el joven W. Benjamin evidencia un gran bagaje intelectual, pero que vienen incisivamente marcados por su experiencia como alumno durante dos cursos -entre 1905 y 1907- en un colegio de Haubinda, en Turingia. Es decir, cuando el alumno W. Benjamin contaba entre 15 y 17 años de edad.

En ellos se evidencian ya ciertas contradicciones, que permanecerán de forma constante a lo largo de su existencia; marxista a partir de su relación con Asja Lacis que lo llevó hasta Moscú ${ }^{13}$ e individualista consumado, jamás integrado en grupo alguno, a pesar de su relación con la Escuela de Fráncfort; interesado por la historia y por su cotidianeidad, idealista y materialista en según qué momentos de su

la juventud escolar", publicado en Der Anfang (junio 1913), bajo el seudónimo de Ardor, pp. 42-46; 6. "Romanticismo: la respuesta del profano" en Der Anfang (septiembre de 1913) utilizando el seudónimo de Ardor, p. 47; 7. "La enseñanza de la moral" (julio de 1913) en Die Freie Schulgemeinde, texto publicado con su nombre, pp. 48-54; 8. "Experiencia" en Der Anfang (octubre de 1913), con el seudónimo de Ardor, pp. 54-56; 9. "Pensamientos sobre el "Festival" de Gerhart Hauptmann", con el seudónimo Ardor, pp. 57-61; 10. "Metafísica de la Juventud" (entre 19134 y 1914), que no llegó a publicarse, pp. 93-107; 11. "Metas y caminos de los grupos pedagógicos estudiantiles en las universidades alemanas (con especial referencia a la "corriente de Friburgo", (1914), firmado por W. B. y publicado en las Actas del Primer Congreso Pedagógico Estudiantil (1914), que tuvo lugar en Breslau el 6 y 7 de octubre de 1913; 12. "La juventud se mantuvo en silencio", publicado en Die Aktion (octubre de 1913), manteniendo el seudónimo Ardor, pp. 67-69; 13. "Veladas literarias estudiantiles", publicado en Der Student (órgano del estudiantado libre de la Universidad de Berlín) (enero de 1914), firmado con su nombre, pp. 70-73; 14. "Educación erótica" (enero de 1914), publicado con el seudónimo de Ardor, en Die Aktion, pp. 73-74; 15. "La posición religiosa de la nueva juventud" (mayo de 1914), firmado por W. B. en Die Tat: Sozial religiöse Monrtsschirift Deutsche Kultur, pp. $74-76$ y 16. "La vida de los estudiantes" (septiembre de 1915), publicado por W. B. en Der Neve Merkur, pp. 77-89. Las páginas indicadas corresponden a la versión española de sus Obras completas, op. cit. Véase libro II, vol. I. Madrid, 2007. En total ocupan 97 páginas de la edición citada.

12. Cabe decir que hemos preferido referir las obras pedagógicas de juventud a partir de la reciente publicación de sus obras completas, para así facilitar la tarea tanto al lector interesado como a nosotros mismos. No obstante ello no es excusa para no haber emprendido antes el estudio pedagógico del joven Benjamin, ya que de hecho estos artículos estaban publicados en castellano, algunos de ellos hace ya algunos, muchos años. Por ejemplo cabría citar las siguientes ediciones: Benjamin (1989, 1993 y 2008).

13. Conoció a Asja (Asia, en castellano), que era letona, nacida en Riga, en 1924, en un viaje a Capri. Entre 1926 y 1927 viajó a Moscú para reencontrarse con ella. Sin embargo, esta visita quizás sea una de las historias más frustrantes de la literatura universal de carácter realista; sabemos esta información por BENJAMIN (1988b). 
vida $^{14}$, estudioso del romanticismo ${ }^{15}$, pero también de Baudelaire ${ }^{16}$ y Kafka ${ }^{17}$; crítico del sionismo político y defensor del sionismo cultural; denunciador de la técnica ${ }^{18}$ y apasionado de la fotografía ${ }^{19}$ y otros medios ${ }^{20}$; solitario casi siempre, pero a la vez enamoradizo consumado y deseoso de compañía, etc. Podríamos extendernos en sus dicotomías y, sobre todo, en sus transiciones, que de hecho ocuparon toda su vida y que, como hemos mencionado, se evidencian de alguna forma a lo largo de su obra. Acaso cabría afirmar que la discontinuidad es una nota característica no sólo de las temáticas que trató sino también de su reflexión.

Por ello mismo, es necesario clarificar una cuestión como mínimo curiosa; de principio cabe decir que Walter Benjamin, como pensador judío que fue, rompe la línea mesiánica de búsqueda de nuevos sistemas abarcadores capaces de transformar la realidad y que den respuesta a todo. De hecho el pensamiento judío se concretiza en aportes de totalidad, que se encuentran tanto en C. Marx, como en A. Einstein, en S. Freud o, más recientemente, en H. Marcuse ${ }^{21}$, y otros muchos intelectuales de su condición. Sin embargo, a pesar de que Benjamin sea por excelencia un escritor con escasa coherencia temática en el sentido de que no realizó una obra unitaria, demuestra, por el contrario, tal cúmulo de intereses, trata de tantas cuestiones dispares, que sin duda estamos también ante un autor abarcador que, a base de puntos y apartes (como muchas de sus obras compuestas

14. Lo que no es óbice para teñir gran parte de su obra de un espiritualismo que puede llegar a tener reminiscencias místicas e incluso esotéricas. La muestra más palpable es su hermético texto Agesilaus Santander (Benjamin, 2004a), que mucho tiene que ver con la angeología judía, y por tanto cabalística, y que dedicó a la pintora Anna M. ${ }^{a}$ Blaupot ten Cate, a la que conoció -y se enamoró de ella- en su segunda estancia en Ibiza ya como exiliado del régimen hitleriano. Véase Scholem (2004, 59-64); de todas formas este autor dice que muy posiblemente la inspiración de este texto tiene mucho que ver con las fiebres que le causó la malaria en la isla. Otra versión de este escrito se publicó en la Revista Nadja de Buenos Aires (Benjamin, 1991a), que estaba dedicada monográficamente a "La huella y el pensamiento judío". Conocemos otra versión publicada en Diario de Poesía. Vid. W. Benjamin (1999b). De todas formas este texto no supone una excepción ya que en la misma línea cabría citar BENJAMIN (1971 y 1987).

15. Vid. Benjamin (1988a).

16. Tal como se evidencia en Benjamin (1972), o en el libro iv, vol. 1 de sus obras completas en castellano, recientemente publicado (2010).

17. Sobre Kafka y entre otros escritos, véase: "Franz Kafka. Construyendo la muralla china", en Obras, op. cit. (libro II, vol. 2). Madrid, 2009.

18. Consúltese por ejemplo "La obra de arte en la época de su reproductibilidad técnica", en Obras, op. cit. Vid. libro I, vol, 1. Madrid, 1996.

19. Véase su famoso texto Sobre la fotografía (Benjamin, 2004b), en el que no falta una divagación histórica sobre la misma.

20. Véase, por ejemplo, "La situación del arte cinematográfico en Rusia", pp. 363-367 de Obras, op. cit. (libro II, vol. 2). Madrid, 2009. Cabe decir que durante su estancia en Moscú casi cada noche asistía a sesiones cinematográficas o a ver representaciones teatrales.

21. Acaso su texto dialógico El final de la utopía sea en este sentido su aportación más preclara. Vid. MARCuSE (1969). 
en base a cortos párrafos ${ }^{22}$ o muy pocas páginas), refiere de alguna forma la cultura europea desde la época barroca hasta su tiempo.

Fruto entonces de estas características tan definidas de sus obras, no quiera el lector encontrar en Benjamin una teoría educativa en el sentido de definición personal de lo que es y considera que debe ser la educación; no, no es éste su objetivo que, a buen seguro, estaría muy lejos de sus pretensiones. Los escritos a los que nos referimos son algunas consideraciones pedagógicas fruto de realidades concretas, que plantean el papel que un tipo de educación determinado -ya lo veremos- podía jugar en la mejora de la juventud y en la transformación de las instituciones educativas. No es pues una aportación cabal ni cabalmente acabada; es, simplemente, Walter Benjamin, en estado puro; es decir, escribiendo en función de sus intereses, de su momento, como hizo siempre a lo largo de su vida.

Reafirmamos nuestra postura de creer que son en estos primeros escritos de juventud sobre aspectos pedagógicos, en donde se intuye la semilla y el origen, la génesis en definitiva, de lo que luego, a lo largo del tiempo, se convertirá no sólo en una característica crucial de su pensamiento: la dialéctica entre intelectualidad y vida, entre razón y existencia. Es como si siempre hubiese tenido presente la obra de Kant que tan bien conocía desde su juventud, en concreto la diferenciación que el rígido profesor de Königsberg hacía entre entendimiento y sensibilidad, aunque en el caso de nuestro autor no sabríamos decir a ciencia cierta si se aplicó a ello con el necesario éxito.

22. Como bien se evidencia en Benjamin (1987a) o ya de manera incontestable, en la que hubiera sido su magna obra, Pasajes (Benjamin, 2006a), aunque parece ser que sólo se trata de apuntes para un verdadero libro y que a pesar de sus 1000 páginas, aún no había acabado de recoger toda la información necesaria para escribirlo. Se dice que en su cartera negra, con la que llegó a Port Bou y que a raíz de su muerte se perdió y jamás fue encontrada, llevaba material para integrar al libro mencionado. Por otra parte, cabe tener en cuenta que es normal encontrar escritos de W. Benjamin de una, o muy pocas páginas, sobre los más variados temas de su interés; en este sentido cabe recordar que en el Origen del drama barroco alemán (BEnjamin, 1990) ya nos advertía que el fragmento es el material más noble de la creación barroca. 


\section{JUVENTUD ESCOLAR}

A través de algunos de sus escritos autobiográficos ${ }^{23}$ así como de la literatura que su compleja vida ha inspirado ${ }^{24}$, se pueden seguir con algún detalle sus años de estudiante, a pesar de sus recelos permanentes en ocultar detalles de la misma, hasta el punto de caer en un férreo hermetismo, fruto de su permanente vergüenza, rayando en el complejo de culpabilidad, por sus orígenes burgueses y capitalistas. Ya desde muy joven se quiso decantar de todo lo que su familia y amistades representaban, y más luego, cuando se afilió a los contenidos políticos y metodológicos del marxismo -el pensamiento crítico-, que hizo que se relacionase con la Escuela de Fráncfort, a través fundamentalmente de Th. Wiesengrund, más conocido por su segundo apellido, Adorno, y, en menor grado, de M. Horkheimer ${ }^{25}$. Esta actitud,

23. En Benjamin (1996a), denotamos un compendio de los diversos apuntes que fue tomando acerca de su vida, muchos de ellos dedicados a recordar su infancia y sus años escolares. Algunas de estas aportaciones han sido incluidas en el presente trabajo, aunque sólo las referidas a sus años juveniles, que son en los que ahora nos centramos. En otro orden de cosas, cabe destacar, por su cercanía, Benjamin (1996b), que escribió en su primera estancia en Ibiza, a caballo entre San Antonio e Ibiza. De todas formas, él ya conocía España, pues en 1925 tras fracasar en su habilitación como profesor de Literatura Alemana Moderna en la Universidad de Fráncfort, viajó a Barcelona (por cierto, no se olvida de citar Las Ramblas), Sevilla y Córdoba. También por unos días conoció Mallorca, en concreto Palma, Valldemossa, Deià y Cala Ratjada, donde se trasladó para estar con la colonia de escritores alemanes que allí residían, entre ellos el redactor del suplemento literario del Neue Zürcher Zeitung, Franz Blei. Vid. VALERo (2008, 125 y 126).

24. Para un conocimiento de la vida de Walter Benjamin destacaríamos, además de sus escritos autobiográficos a los que hemos hecho referencia: Lane (2005); Witte (2002); Wolin (2002); Tiedemann, Gödde y Lonitz (1981). La Revista de Ciencias Sociales, en su número de junio de 2003, publicó un monográfico sobre W. Benjamin en el que se da cabida a diversos artículos sobre su biografía. También interesan Scholem (2004) así como P. MisaAc (1997). Para su estancia en Ibiza nada mejor que la exhaustividad de VAlero (2008). Asimismo, cabe consultar de su amigo de la época de Ibiza, Jean Selz, "Walter Benjamin à Ibiza" (SElz, 1954). Otra fuente interesante son las "introducciones" que escribiera Javier Aguirre, verdadero mentor de la obra de Benjamin en España, en los libros que publicó de nuestro autor en la editorial Taurus de Madrid. También cabe decir que, con las licencias que la creación literaria impone, se han novelado las últimas horas de su vida; véase CANO (2000). Nuestra aportación se fundamentará en estos textos, bien entendido que sólo nos referiremos al Benjamin estudiante, obviando otras etapas de su vida, ya que se escapa por completo a nuestros en verdad, en esta ocasión, menguados intereses.

25. No seremos nosotros quienes neguemos las relaciones estrechas de Benjamin con la Escuela de Fráncfort, ya que posiblemente fue uno de los autores que más aplicó y más radicalmente la teoría crítica en sus obras, cuestión ésta que Adorno le objetaba por el rechazo social que podían tener sus escritos. También cabe recordar que conoció a T. Adorno en 1923 y algo más tarde a M. Horkheimer, en 1925, en ocasión de su frustrado empeño de acceder a un puesto de docente en la Universidad de Fráncfort; además fue Adorno quien le envió el salvoconducto para que llegase a Estados Unidos y quien después de su muerte se encargó de difundir su obra. Vid. la introducción de MuÑoz (1998). Ahora bien, esta pertenencia era más ideológica que otra cosa ya que Walter Benjamin siempre manifestó su independencia y cierta lejanía física y grupal con los demás miembros de tal grupo. La colaboración con la Escuela viene más determinada por la necesidad crematística que no por otra cosa, ya que es sólo en 1933, cuando debido a su necesidad económica, acuciada aun más por su exilio 
sin duda, nos ha dejado huérfanos de muchos aspectos de su educación familiar y del contexto en el que creció y se formó, lo que ha influido de forma negativa en el conocimiento de esta primera etapa de su vida.

Hay que considerar que Benjamin era el hijo mayor (de tres hermanos) de un corredor de arte y hombre de múltiples negocios que llegó a alcanzar una elevada fortuna y una alta posición social entre la más selecta burguesía del Berlín finisecular ${ }^{26}$; por tanto, no debe sorprendernos que sus estudios primarios los hiciese con preceptores particulares que reunían a un selecto y escaso número de alumnos de ambos sexos de la alta burguesía judía berlinesa. Obviamente, a los diez años, tuvo que prepararse para el ingreso al Gymnasium y acceder así a los estudios secundarios -bachillerato, en aquella época- para lo cual tuvo también un profesor particular, que -el detalle creemos que no es baladí- más que enseñarle contenidos, le dio clases de lo que hoy en día se denomina enseñar a aprender o a estudiar, o propedéutica, tal como afirman algunos de sus biógrafos. Sin problemas, en 1902, a los diez años de edad, ingresó en el Gymnasium Kaiser Friedrich, situado en la Plaze Savigny de Berlín ${ }^{27}$.

Con los antecedentes mencionados no debe extrañarnos que el joven Walter no se adaptase a la enseñanza pública por muy elitista que fuese su centro; sus angustias, miedos, desasosiegos y escaso rendimiento, desarrollando además cuadros clínicos de carácter psicosomático, debido especialmente al clima disciplinario del centro, harán que sus padres lo internen en un colegio privado situado en Haubinda $^{28}$, a medio camino entre Berlín y Sttugart y bastante próximo a Fráncfort.

ibicenco, acepta un encargo que a modo de ayuda encubierta le proporciona Max Horkheimer, a la sazón director del "Instituto para la investigación social", fruto del cual es su ensayo "Sobre la situación social que el escritor francés ocupa actualmente", que puede leerse en Obras (Madrid, 2009), libro II, vol. 2, pp. 393 y ss., op. cit. Queremos decir que ni la amistad ni la ideología ni la proximidad ideológica y afectiva hicieron descabalgar a Benjamin de su individualidad e independencia personal. En referencia a la amistad con Adorno, cabe mencionar la confianza que existía entre Benjamin y Gretel Karplus, la futura esposa de aquél, que le enviaba dinero para aligerar su situación económica y a la que Benjamin llamaba "Felizitas"; en su amplia correspondencia, siempre hablan, refiriéndose a Adorno, como el "niño problemático". En una carta, escrita el 25 de junio de 1933, W. B. le propone a Gretel que él sea su "niño adoptado". Vid. Benjamin (2008a, 225).

26. Se trataba de Emile Benjamin (1866-1926), siendo Pauline Schönflies su esposa, y madre de Benjamin, hija a su vez de una familia de comerciantes agrícolas asimismo de notable posición. Además de a Walter, tuvieron a Georg, nacido en 1895, militante del partido comunista, y que murió en el campo de concentración de Mauthausen en 1942, y a Dora, que vino al mundo en 1901, estudió medicina y psiquiatría y murió en Suiza en 1946 y con la que siempre tuvo una relación dificultosa y ambivalente. No así con su hermano al que adoraba. Para tal información vid. Lane (2005).

27. Tal denominación está dedicada al ministro prusiano Karl von Savigny; se trata de una plaza con un aire romántico, debido a la estética que le propicia su vegetación, y separada del centro político de Berlín por el amplio parque de Tiergarten.

28. Este hecho es recogido por Jarque (1992, 23 y 24). Para una mayor comprensión de lo que se dirá a continuación de este colegio cabe decir que Haubinda es una pequeña aldea que hoy en día -2010- no llega a los 80 habitantes. 
Esta escuela pasaría con los años a formar parte de la historia de la "escuela nueva" alemana, y pese a que, cuando ingreso W. Benjamin en ella, aún no hacía muchos años de su inauguración (1901), ya gozaba del prestigio de ser una escuela "diferente", puesto que, tal como se reconoce en alemán, se trataba de una escuela "reformada", contraria entonces al espíritu de las escuelas tradicionales.

La clave del interés tan temprano de W. Benjamin por la pedagogía reside exactamente en los dos años que pasó en este centro, y ello debido a la experiencia educativa que vivió y al espíritu formativo que había implantado su director, Gustav Wyneken. Tanto es así que, durante algunos años, Wyneken será su mentor y orientador intelectual hasta tal punto que los 16 artículos que analizaremos están casi todos ellos inspirados por la obra teórica y práctica del mencionado director de Haubinda.

Esta escuela se trataba de un Landerziehungsheim, u "Hogar de educación en el campo", que fueron característicos del movimiento de la escuela nueva o "reformista alemana", y cuya existencia se prolongó hasta 1934, cuando fueron clausurados por el régimen nacional-socialista. El caso del «Hogar» en el que estuvo Wyneken es digno de mencionarse porque en él había profesores que bebieron directamente de la primera experiencia "nueva" de educación que se implantó en Europa, tal como era el caso de Hermann Lietz, antiguo colaborador de Cecil Reddie en Abbotsholme, Derbyshire, Inglaterra ${ }^{29}$. La educación que aplicaba Wyneken, que hacía las funciones de director del colegio, se basaba en la creación de un ambiente familiar, cercano, imitando a la vida sencilla de las granjas de los alrededores; es decir, se estudiaba, en general, por las mañanas y se trabajaba por las tardes en tareas agrícolas y en otras manualidades; el espíritu era comunitario, grupal, con ciertos niveles de autogestión, y, en consecuencia, se creaba un clima

29. Cecil Reddie fue alumno directo de J. Dewey, cuando era catedrático de la recién creada, por el magnate Rockfeller, Universidad de Chicago, donde conoció las famosas "Escuelas laboratorio" que Dewey había instituido siguiendo en parte los dictados de Alice, su esposa, siempre interesada por la educación y en parte causante de que su marido se dedicase a ella. Reddie, de regreso a Inglaterra, en una de las fincas de su padre -Abbotsholme- creó un centro al que denominó "New School" -de aquí la denominación que luego se extendería a todo el movimiento escolar que se generó años más tarde. Pues bien, uno de los profesores colaboradores de Reddie era Hermann Lletz, que en el año 1898 fundaría imitando a la "New school" su primer Landerziehungsheim, en Ilsenburg, o primera experiencia reformista alemana; este centro estaba dedicado a alumnos de 8 a 12 años, lo que hizo, visto el éxito de la experiencia, que en 1901 crease otro centro similar para niños entre 13 y 16 años en Haubinda, en donde W. Benjamin fue alumno entre los 13 y 15 años. En este centro trabajaban Gustav Wyneken y Paul Geheeb, hombre este último también clave en la pedagogía reformista alemana, ya que en 1909, al abandonar el centro de Haubinda, creó su propia experiencia pedagógica en Odenwald, a la que denominó Schuigemeinde o "comunidades escolares". Ambos modelos se extendieron por Alemania y Austria con cierta profusión, protagonizando, en definitiva, el movimiento de la escuela nueva -reformistas, en alemán- en ambos países. Vid. LuzuRIaGa (1929). 
de libertad y compañerismo ${ }^{30}$ que también se extendía a las relaciones entre profesores y alumnos, en que ambos tenían los mismos derechos, al estar unidos por los mismos objetivos; sin duda todo ello impactó en el joven Benjamin, sobre todo tras la experiencia que había tenido en el Gymnasium de Berlín, en donde eran frecuentes las vejaciones y los castigos físicos.

Por otra parte, no hay duda de que se trataba de una escuela nacionalista y de alguna forma pangermanista, donde se cultivaba el deseo de "formar una juventud al modo alemán, sana de cuerpo y alma... que ame a Dios, a la patria y a los hombres", y en donde se buscaba "el desarrollo del espíritu, de la voluntad y de la inteligencia para que con ellas se pueda servir eficazmente a la nación " ${ }^{31}$. En definitiva, las características del pensamiento pedagógico de Wyneken se fundamentaban en cuatro núcleos a los que dedicó sus escritos más consistentes; nos referimos a:

- $\quad$ El idealismo, propio del pensamiento alemán desde que Hegel concibiera su teoría del Estado y que Fitche se encargara de adaptar a la educación a través de sus Cartas a la nación alemana, y que luego de manos de Schiller ${ }^{32}$ con sus Cartas sobre la educación estética del hombre, Schelling con sus Lecciones sobre el método de los estudios académicos ${ }^{33}$ y otros filósofos, fueron acercando el idealismo a la pedagogía, lo que culminaría en Dilthey y en la escuela de Maburgo. Este idealismo acompañaría a W. Benjamin durante todos estos años a los que nos vamos refiriendo.

- El "eros pedagógico" o amor -estima, diríamos nosotros- que el profesor debe tener para con sus alumnos, de donde extraería de entre otras notas el sentido de la amistad, el clima de confianza, la libertad, la independencia y autogestión, etc., que deben impregnar el centro educativo, y que, a su vez, deben ser el vértice de las relaciones entre profesores y alumnos.

- En tercer lugar, pero no por ello menos importante, nos encontraríamos con el concepto de Jugendkultur, o cultura juvenil, con el que Wyneken quería patrocinar una diferenciación específica del joven en referencia al adulto y que, como consecuencia, toda su formación debía asentarse y aun propiciar este hecho diferencial. Educar tenía que ser pues lograr que el joven se desarrollase como tal, y la escuela, a su vez, tenía que posibilitar soluciones a todas sus necesidades, ambiciones e intereses juveniles; la escuela tenía que ser entonces el foco que iría alumbrando

30. Incluso se dice que las teorías de Wyneken tuvieron cierta influencia en la constitución de los Kibutz, especie de granjas colectivizadas, en donde se educaba a niños y jóvenes, una vez creado el Estado judío en Israel.

31. Vid. LuZuriaga (1929, 19).

32. Sobre este autor y para el contexto en el que nos movemos, véase SAFranski (2006).

33. Para las obras citadas de estos autores véase respectivamente Fitche (1988), Schiller (1990) (ambas obras se publicaron hace años en la colección Austral de Espasa-Calpe) y ScHELLING (1984). 
esta cultura juvenil que luego se tendría que extender a todos los ámbitos de la vida del estudiante, incluso en sus tiempos de ocio y fuera de la escuela; de ahí que Wyneken fuese el creador de los movimientos juveniles alemanes, de alguna manera inspirados en el escultismo, sobre todo en su parafernalia externa, más que en sus contenidos y presupuestos.

- Por último, hablaríamos del sentido comunitario en el que debe incardinarse todo el proceso educativo y que, en consecuencia, sería el factor coadyuvante para lograr la cultura juvenil, así como la expresión de los valores que deben ornarlo. La moral, el patriotismo, el cumplimiento del deber, el trabajo, todo en la escuela debe tener un sentido comunal. Fuera de la comunidad no hay educación posible.

Pues bien, el aspecto que más cautivó a Benjamin del bagaje ideológico de Wyneken, asentado en la tradición idealista alemana, de la cual él participaba, fue de forma fundamental su concepto de Jugendkultur -cultura juvenil- que luego reiteraría en los escritos que analizaremos. También, aunque lo manifiesta de una forma más ambigua, se dejó influenciar, en parte, por el sentido comunitario que de la educación poseía Wyneken, ya que no podemos olvidar que W. Benjamin vivió tal experiencia a lo largo de sus dos años de escolaridad en Haubinda. En cambio del "eros pedagógico", o estima que el profesor debe tener para con sus estudiantes $^{34}$, no hemos encontrado rastro alguno en sus escritos pedagógicos. En concreto dos fueron las influencias que Benjamin extrajo de esta experiencia formativa, el pensamiento idealista y luego, más concretamente en el contexto de la cultura juvenil, el interés que siempre manifestó por la libertad, todo ello bajo los epígrafes, como decimos, de la tradición filosófica del idealismo alemán. No nos extrañe entonces que en sus años de estudiante -y dirigente- universitario pretendiese la reforma de la Universidad a través de la cultura juvenil, casi como sinónimo de cultura de libertad, sin renunciar por supuesto a su contexto idealista ${ }^{35}$.

34. Wyneken era homosexual, por lo que difícilmente pudo pertenecer al partido nazi, aunque en este sentido mantuvo siempre una postura ambigua. Asimismo su influencia es manifiesta en Paul Goodman, también homosexual y autor entre otros libros de Goodman (1974, 1975 y 1976). No obstante es en GoOdman (1970) donde la influencia de Wyneken es más manifiesta. Hay que tener en cuenta que cuando Wyneken abandona la escuela de Haubinda para fundar su propia experiencia reformista (paralelamente a lo que había hecho su colega Paul Geheeb), la denominó "Comunidad escolar libre"; estaba situada en Wickersdorf. Véase de nuevo el libro de Luzuriaga (1929, 28 y ss.). Ésta es la tesis que defiende WyNEKEN (1926, 507-511).

35. Muchos de sus biógrafos coinciden en señalar que el fin de su etapa idealista se consuma a raíz del suicidio de una pareja de amigos suyos con los que mantenía una estrecha relación; se trataba del joven poeta Fritz Heinle y de su novia Rika Seligson, hermana de Carla, amiga a su vez de W. Benjamin. Parece ser que la causa del suicidio de la pareja fue el pavor que les producía el inicio de la guerra. Por otra parte, el conocimiento personal y de la obra de Ernest Bloch, entre 1917 y 1918, fue sin duda un motivo, diríamos más intelectual y racional que emotivo, para marginarse ya para siempre de las tesis idealistas. En los años posteriores se ira denotando el abandono de la hermenéutica heideggeriana centrada en el Dar sein, aunque por otra parte siempre manifestó interés 
Cabe decir que el sentido de la libertad en la educación siempre interesó a G. Wyneken, que lo aunaba con la misión del espíritu, así como con la cultura juvenil, hasta tal punto que el desarrollo del espíritu a través del arte, del conocimiento científico y del desarrollo de la sensibilidad tenía que desembocar en la formación de un Estado cultural, puesto que «la verdadera escuela ha de corresponder al trabajo espiritual de la época en la que ha de introducir; así también tiene que acomodarse aquella a la naturaleza de la juventud ${ }^{36}$; en este mismo texto, más adelante, afirma "mi colaboración en el progreso del espíritu es el sentido de mi vida", teniendo en cuenta que la cultura -que no se olvide se transmite mediante la educación- es el "sistema de nuestra posesión espiritual objetiva" ${ }^{37}$. Otro de los aspectos característicos de la pedagogía de G. Wyneken, tal como mencionábamos, era el espíritu comunitario de tal manera que, como dejó escrito, "la comunidad que se educa a sí misma será en adelante el único objeto y sujeto de la educación" "38, lo que no caía en contradicción alguna con el idealismo ya que lo comunitario era a la vez la cuna para formar a los jóvenes en las prescripciones del espíritu.

En fin, brevemente hemos intentado reseñar el caldo de cultivo ideológicopedagógico del que hará gala algunos años después Walter Benjamin, cuando se interese por la cuestión pedagógica relacionada con la juventud, con la cultura juvenil y con el desarrollo del espíritu, en total consonancia pues con su profesor en Haubinda. No obstante, la admiración por su maestro se rompería pronto, de hecho a partir de 1913 empezaron los titubeos, y de forma definitiva en 1914, tras la apasionada defensa de la guerra y de la necesidad de la misma que realizara Wyneken (inicios de la primera contienda mundial) y que chocó frontalmente con el sentido pacifista de nuestro autor.

Pues bien, Walter Benjamín estuvo dos años interno en este colegio, al término de los cuales regresaría de nuevo a Berlín. El motivo de su traslado a su antiguo Gymnasium no lo especifican sus biógrafos, pero teniendo en cuenta que culminó sus estudios de bachillerato -el Abitur- nada menos que a los veinte años, nos imaginamos que sus padres debieron ver un lento proceso cultural que no era conveniente prolongar por más tiempo. Fue en esta segunda etapa, en el mismo centro público de sus inicios de estudiante de bachillerato, cuando notó por primera vez algún tipo de discriminación por parte de sus compañeros de estudios por motivo de su raza. Es decir, desde muy joven, fue consciente de su judaísmo y de lo que suponía ser judío en su país.

por la hermenéutica de lo concreto, aunque el materialismo será su posicionamiento más convincente. El conocimiento y la influencia de Asja lo definirán ya plenamente en este último sentido.

36. Vid. WYNEKEN (1927a, 409-413).

37. WyNeKEN (1927a, 411 y 412), respectivamente para las dos citas.

38. Véase Wyneken (1927b, 169) del primer volumen. Se trata de la obra más importante del autor que tenemos traducida al castellano, traducción que por cierto realizó L. Luzuriaga. 
También tuvo que sufrir, una vez más, las vejaciones, castigos y mal trato que eran habituales en su Gymnasium, lo que le siguió propiciando enfermedades psicosomáticas para no asistir a clase, falta de atención, escaso éxito en los estudios, etc. Todo ello hizo que se retrasase en la culminación de los mismos, y que, a pesar de su experiencia escolar con Wyneken, comenzase a odiar a las colectividades, encontrando refugio en la salvaguarda de su individualidad, algo que ya sería permanente a lo largo de su vida, a pesar de sus futuras afiliaciones ideológicas, muy posiblemente para llevar la contraria a la cultura burguesa de su familia. Nos encontramos ya en la perenne contradicción de la que Benjamin hizo gala toda su vida y que de alguna forma fue un acicate importante a través del cual gestó su obra.

Contradicción que se hará más patente en su etapa de estudiante universitario cuando en base a la organización de grupos de estudio pretendió desarrollar una "Cultura juvenil independiente". Benjamin inició sus estudios superiores el trimestre de verano, tras acabar, por Pascua, los propios del bachillerato; ingresó en la Universidad de Friburgo, para estudiar Filosofía, en donde tuvo de profesor a Heinrich Rickert $^{39}$. Allí se afilió a la "Sección para la reforma escolar", integrada dentro del Freie Studentenschaft o "Asociación de estudiantes libres" -O sea, no pertenecientes a partidos políticos-. Esta sección para la reforma escolar se había creado el invierno de 1911, o sea, unos meses antes de iniciar Benjamin sus estudios universitarios. Su dedicación fue tal que abandonó casi por completo los estudios de tal manera que, como nos reseña uno de sus biógrafos, Bernd Witte, en junio de 1912, escribió a un amigo suyo, compañero del Gymnasium que se había quedado en Berlín, H. Belmore, diciendo que se consideraba "héroe de la reforma escolar y víctima de la ciencia " ${ }^{40}$.

Pronto destacó por defender las tesis más radicales de la Asociación, así como el derecho de los estudiantes a participar en la organización universitaria, en un intento de lograr un cambio social a través de una revolución cultural, lo que sólo sería posible en una universidad más comprometida con la autodeterminación; en definitiva, buscaba una Universidad más libre, puesto que sólo con libertad y en libertad se podría conseguir una mayor producción intelectual y, en definitiva, el desarrollo de una cultura no contaminada por los vicios de la sociedad.

Benjamin alternaba los semestres entre dos universidades, ya que en invierno estudiaba en Berlín, donde también pronto destacó por su activismo, creando entre 1912 y 1913 una sociedad de debate, Sprechsaal, que se reunía en un piso que sus componentes habían alquilado y al que denominaban Das hem, "El hogar"; con ello quería formar una sociedad libre con formas de vida libre, lejos de la

39. H. Rickert era representante de la línea culturalista e idealista de la educación que de alguna forma había iniciado Dilthey. En castellano puede consultarse la que posiblemente sea su obra pedagógica más importante, Vid. RickerT (1945), con prólogo de J. Ortega y Gasset.

40. WiTTE $(2002,24)$. 
vigilancia ejercida por los padres; como veremos, sus escritos pedagógicos de este año abundan en críticas sobre los padres por su escepticismo, su pasividad en la acción y por lo que el joven Benjamin denomina la "experiencia de los filisteos", en referencia a la "moral de los mercaderes", es decir, la propia de la burguesía ${ }^{41}$. También a destacar en este mismo contexto sus escritos sobre sexualidad.

En el semestre de invierno de 1913-14, llegó a presidir la "Asociación de estudiantes libres" de la Universidad de Berlín, en donde, a través de sus proclamas y discursos, se haría muy impopular entre los estudiantes. Benjamin, por una parte, va radicalizando sus posiciones y comienza a negar en parte la influencia de Wyneken; así, en ocasión del "Primer Congreso pedagógico estudiantil» llega a afirmar "no somos unos fanáticos partidarios de Gustav Wyneken..." ${ }^{42}$, si bien a continuación se explica más claramente al decir "no estamos intentando averiguar a cuál de los reformadores escolares de hoy hay que seguir, sino que estamos intentando desarrollar las cosas a partir de nosotros mismos" ${ }^{43}$. Será también en esta época cuando comience a criticar el compromiso político de los estudiantes diciendo que con la politización lo que se consigue es satisfacer la necesidad de los partidos políticos y no las necesidades de la juventud, de una verdadera cultura juvenil, ya que con la politización se va cayendo en la alienación; por tanto, es falso el interés que el estudiante pueda sentir por el proletariado, porque esta actitud no es propia del espíritu de los jóvenes, sino que es más bien una manipulación de los adultos en favor de sus intereses y, por ello mismo, una invasión en toda regla del espíritu juvenil.

Estos planteamientos harán que sea acusado de elitista y que sea rechazado dentro de su Asociación, hasta tal punto que no sólo dimitió de su cargo de presidente, sino que incluso tuvo que abandonar la propia Universidad. Las tesis de Wyneken, la idea de lograr una Universidad basada en el espíritu, verdadera creadora de la cultura de la juventud, no tuvieron en realidad ningún predicamento entre la propia juventud universitaria. Tras su fracaso, verá como su maestro y guía publicaba en 1914 Juventud y guerra, un panfleto a favor del belicismo en el que llama a la juventud alemana a participar en lo que sería la primera contienda mundial. Con ello la relación tanto personal como ideológica con Wyneken se

41. Es interesante consultar su artículo "Enseñanza y valoración", op. cit. Obviamente las relaciones entre Walter Benjamin y su padre siempre fueron muy difíciles y en según qué momentos inexistentes. No debe pues sorprendernos la crítica a la burguesía, a la cual él pertenecía y que conocía tan bien; es decir, no se debía sólo a motivos ideológicos, ya que a ello había que sumar su intento por desclasarse y su conocimiento profundo de los valores y de la moralidad burguesa de la que su familia era un claro y exponente ejemplo.

42. Este Congreso se celebró en 1913 y se publicó al año siguiente en 1914. Lo citaremos por Benjamin (1913f). Vid. en Obras, libro it, vol. 1, op. cit., p. 65.

43. Ibid. 
enfriará definitivamente. Tras lo ocurrido en Berlín, Benjamin se matriculará en la Universidad de Múnich, de cuyo profesorado hará una dura crítica.

En 1917, obtiene el título en la Universidad de Múnich; se casa este mismo año con Dora Pollack ${ }^{44}$, y se instalan en Berna, Suiza, en donde cursará los estudios de doctorado. En 1918 nace su único hijo, Stefan Rafael ${ }^{45}$. Al año siguiente culminaría su tesis El concepto de crítica de arte en el romanticismo alemán ${ }^{46}$ calificada cum laude $^{47}$.

\section{Pedagogía}

Como hemos venido reiterando, los trabajos de juventud de Walter Benjamin fueron escritos entre 1911 y 1915, es decir, entre los 19 -aún no había obtenido su Abitur en el Gymnasium- y los 23 años, aún estudiante, a punto de proseguir sus estudios en Múnich, tras su fracaso como lider juvenil. Como hemos venido mencionando, en ellos se ve la influencia de Wyneken, de tal manera que podríamos resumir las temáticas que trata en base a tres conceptos: idealismo, cultura y juventud. Son, por otra parte, escritos que evidencian el momento vital de su autor,

44. Dora y Walter se separaron en 1930; en aquellos momentos Walter y la letona Asja Lacis mantenían una relación desde su encuentro en Capri en 1924; incluso en 1929, Asja se trasladó a Berlín para vivir cerca de Benjamin, lo que, sin embargo, provocó su separación definitiva. A pesar de ello, el matrimonio comenzó a tener problemas a partir de 1920, con infidelidades por ambas partes.

45. De Stefan Rafael Benjamin (1918-1972), sólo hemos podido recabar información a través de la correspondencia que desde Ibiza mantuvo Walter con su exesposa; son noticias desperdigadas en las que es difícil introducir coherencia. Sabemos que de muy joven -a los 14 años- ya se declaraba comunista; también nos consta la preocupación de Walter por la suerte de su hijo, que en aquella época vivía (junto con su madre) y estudiaba en Viena. Al fin parece ser que pudieron instalarse en el Reino Unido. Vid. Benjamin (2008a, 5, 4, 64, 102, 140, 151, 171). También son evidentes los recuerdos y la presencia que en sus viajes tenía su hijo al que le compraba un sinnúmero de juguetes. Por esta misma fuente hemos tenido acceso al testamento de W. Benjamin que redactó en Niza el 27 de julio de 1932, a raíz de un intento de suicidio no consumado. En él consta que su biblioteca, algunos cuadros y una cantidad entre el 40 y el $60 \%$ de lo que puedan devengar sus escritos vayan a manos de su hijo Stefan (vid. pp. 76-80). En la p. 102 por una nota a pie de página sabemos que G. Scholem se encontró en Londres con el hijo de su amigo en 1946. Para mayor abundamiento véase SCHOLEM (1987).

46. Véase Benjamin (1988a).

47. De todas formas la vida académica de Walter Benjamin no acabaría aquí, ya que en 1924 se interesa en obtener la Venia legendi en la Universidad; en primer lugar pensó en optar en Heidelberg a una plaza de Filosofía de tal manera que incluso se trasladó allí; al ver la dificultad que entrañaba, se decidió con el padrinazgo de algunos profesores a presentarse a una plaza de Literatura Alemana Moderna en la Universidad de Fráncfort, para lo cual presentó su trabajo El origen del drama barroco alemán (vid. Benjamin, 1990), que fue rechazado por confuso, místico y simbólico, en definitiva, por no adaptarse a las normas académicas. Por último pretendió optar a una plaza de Estética, a lo que Horkheimer, a la sazón profesor en Fráncfort, se opuso. Parece ser que W. Benjamin jamás supo de esta negativa. Vid. para estas cuestiones Scholem (2004). 
sus intereses, las cuestiones que en aquella época le afectaban, incluso su situación vital en cuanto miembro de la "Asociación de estudiantes libres" en las dos universidades donde estudiaba al unísono. Pues bien, de todo ello se desprenden unas afirmaciones radicales, impetuosas diríamos, que sin embargo revelan el momento y el contexto en el que estuvieron escritas.

Por lo demás, decir que no son escritos -al menos la mayoría de ellos- de carácter unitario, ya que sus ideas se reiteran en casi todos ellos; tienen pues más la condición de amalgama antes que ser estudios monográficos sobre cuestiones concretas. De ahí que nuestra primera tarea haya sido ordenar -hasta donde nos ha sido posible- las ideas que en ellos desarrolla, a través de una serie de apartados para así mejor visualizar sus planteamientos. Además con este ejercicio esperamos dar razón del subtítulo que hemos introducido, ya que en esos artículos pedagógicos encontramos algunos de los aspectos que luego serán esenciales y muy propios del complejo pensamiento de nuestro autor.

\subsection{Contexto general: idealismo, cultura y juventud}

Ya en su primer trabajo pedagógico, y posiblemente el segundo de sus escritos que vio la luz pública (Benjamin, 1911) ${ }^{48}$, realiza un símil cargado de idealismo, que antes que ser propio de la edad (que también) es ya síntoma de su momento ideológico; aquí compara a la juventud con la "bella durmiente" del famoso cuento, para afirmar que la juventud se encuentra en la situación de la bella durmiente sin saber que un príncipe pronto la despertará de su letargo. Es decir, la juventud no es consciente de sus posibilidades y capacidades, ni tan siquiera puede imaginar la fuerza y el futuro que le espera. A través de definiciones o aproximaciones al concepto de juventud en Schiller, Shakespeare, Goethe, Ibsen, etc., va desentrañando el hecho de que la juventud debe ser un anhelo colectivo -consciente de sí misma- que aspire al logro del ideal de humanidad que lleva implícitamente. Claro que para ello requiere siempre de la comunidad, puesto que lo que es propio de la juventud -su cultura- despierta en la comunidad y es comunitariamente donde mejor puede desarrollarse. Desde un principio, pues, encontramos ya dos aspectos propios de esta época de Walter Benjamin, el sustrato propio del idealismo alemán desde Hegel y la influencia de G. Wyneken ${ }^{49}$.

48. Como todos sus escritos pedagógicos de juventud están publicados en Obras (2007, vol. II, libro 1. Madrid, Abada), para no utilizar 16 letras para referir sus diferentes escritos y utilizar en ellos el mismo año, 2007, hemos elegido la alternativa de citarlos por el año de su escritura y determinarlos con letras de forma consecutiva, manteniendo eso sí el orden cronológico de su producción. De esta forma, además, el lector tiene constancia exacta del momento histórico en el que fueron escritos.

49. Siempre se ha visto a G. Wyneken y su movimiento de juventud como un precedente e inspirador de las juventudes hitlerianas, coadyuvantes juveniles de la concepción del Estado hegeliano, 
No nos extrañe entonces que Benjamin (1912a, 14) defina la educación como la reproducción de los valores espirituales, si bien también confiesa a continuación que siempre somos más que nuestro presente, en el sentido de que lo que la educación debe hacer es cultivar las posibilidades de nuestro desarrollo natural, hacia adelante, hacia el futuro, y ello no sólo en referencia al individuo, sino extrapolándolo a la humanidad. Claro que para nuestro autor la humanidad y sus valores no son otra cosa que la cultura (1912a, 15).

Obviamente ante tal afirmación nos explica que la juventud está adormecida por el narcótico del individualismo cuando toda ella es esperanza, amor y admiración (1913a, 43); esta contradicción le lleva a criticar uno de los estereotipos más propios de la juventud, ya que considera esta etapa de la vida humana como un "falso romanticismo" (ibid.). La tesis del romanticismo en la juventud supone ensalzar lo individual, hacer creer que cada uno de los jóvenes es extraordinario por sí mismo, porque todo él es potencia, es fuerza y vigor; ante tal posición Benjamin declara que estos argumentos son los propios del falso romanticismo que pretende denunciar, ya que es el camino que lleva al logro de una juventud apolítica y desinteresada, encerrada en los valores del yo y de sus propias aspiraciones. A ello opone el devenir de la humanidad y un concepto de cultura propia de esta humanidad entendida como comunidad, como pueblo, y no en el sentido de cultura como logro de gestas individuales, si bien ésta es y ha sido la forma como siempre se nos ha contado la historia en la escuela ${ }^{50}$.

W. Benjamín tiene pues muy claramente entendida la metodología hegeliana; es necesario pues un nuevo planteamiento, una síntesis resultante de sus manifiestas oposiciones; no nos extrañe entonces que escriba: "Hay que encontrar una salida al conflicto entre desarrollo natural y veraz (de una parte) y la tarea de transformar al individuo natural en individuo cultural (de otra parte), una tarea que nunca podrá llevarse a cabo sin violencia" (Benjamin, 1912a, 15). En otra ocasión escribirá "lo distintivo en la vida del estudiante es la voluntad de oposición" ya que "la sumisión sin críticas ni resistencia es un rasgo esencial de la actual vida estudiantil» (Benjamin, 1915, 78 y 79). Aquí pues el sentido revolucionario,

\footnotetext{
que acaso por primera vez desarrollase Fitche en sus Discursos a la nación alemana, en donde, sin embargo, sus planteamientos pedagógicos eran los propios de J. E. Pestalozzi. En el campo de la literatura sería interesante la lectura de la novela de Mussil (2002). Sobre este libro se realizó una muy buena película, Der Junge Törless, con cuyo mismo título se estrenó en España (El Joven Törless). Se produjo en 1966 siendo su director y guionista Volker Schlöndorff. Fue interpretada por Mathieu Carrière, Marian Seidowsky y Bernd Tischer, en sus papeles más importantes.

50. Ni que decir tiene que gran parte de la obra de Walter Benjamin es de carácter histórico, siendo además reconocido como uno de los filósofos de la historia imprescindibles del siglo xx. Toda su obra de crítica literaria está impregnada por el sentido historicista que siempre aporta el autor; sin embargo, más concretamente cabría citar sus estudios sobre filosofía de la historia. Vid. Obras (2007, libro II, vol. 1. Madrid, Abada, pp. 93 a 239).
} 
transformador que, desde sus primeros postulados idealistas, está presente en el militante universitario, trabajando en pro de un cambio radical de la Universidad, y de la cultura universitaria, tal como ya vimos en los apuntes realizados sobre su experiencia vital de esta época.

En estos años, Benjamin cita ya a Nietzsche en función de sus intereses, pero sin llegar a intuir aún el papel que el autor de El origen de la tragedia griega jugará en la filosofía alemana como crítico radical de las escuelas neokantianas y, en general, de la filosofía idealista alemana del siglo $\mathrm{XIX}^{51}$. Decimos esto porque a propósito de la juventud afirma que el adulto es todo él experiencia; experiencia de su propia juventud, de sus ideales, esperanzas, de las múltiples circunstancias de su vida. En cambio en referencia al joven -y aquí cita a Así hablaba Zaratustra"uno solamente se experimenta a sí mismo" (Benjamin, 1913d, 56), de ahí los fallos y errores que se cometen, aunque basándose ahora en Spinoza no duda en afirmar que "el error es tan sólo una nueva ayuda hacia la verdad" (Benjamin, 1913d, 55).

El joven no es adulto, es joven, y se debe aceptarlo tal como es; de ahí que sea necesaria arraigar una cultura propia de la juventud, una verdadera cultura juvenil que lo haga protagonista de su vida y de su evolución hacia valores más perfectos a los que debe aspirar la humanidad, y que sólo los jóvenes, gracias a su inexperiencia, a su no contaminación del mundo de los adultos, pueden ir consolidando. La juventud, pues, como la antítesis a la sociedad en la que vive; una conformación cultural de la juventud, como idealidad propia, supondría para el día de mañana una nueva sociedad. Para ello se debe poseer una nueva "pedagogía filosófica" -idealista en este caso- que debe enseñar el camino para el logro de los nuevos valores culturales juveniles (Benjamin, 1913f, 66).

En definitiva, en estas cuestiones, Benjamin se decanta por una concepción de la juventud como sentimiento (tras su reconversión marxista, diría como clase), en la que está virginalmente instituido el espíritu que debe desarrollar y alcanzar. Para ello será básico no afiliarse a las culturas de los adultos para ir logrando una cultura propia que sea el seguro de su desarrollo espiritual, libre de toda influencia, gracias a lo cual el ideal de humanidad avanzará en su perfección. Obviamente, años más tarde, tras su viaje a Moscú, entendió que su lucha e ideales en estos primeros años fue una tentativa, más que heroica ingenuidad, de transformar al hombre -en este caso al joven- sin interesarse por la transformación de su contexto social. Era en el fondo el punto de partida de la pedagogía de A. S. Makarenko, el hombre nuevo sólo surgiría de la nueva sociedad.

51. Creemos que es interesante en este sentido aproximarse al estudio de LöwıTH (2008). 


\subsection{La reforma de la escuela}

Acaso sea la temática más importante en la obra pedagógica de juventud de Walter Benjamin, porque a partir de tal cuestión, que juega el papel de núcleo de su pensamiento en estos momentos, irán surgiendo las otras cuestiones que también merecieron análisis desde la educación; nos referimos, por ejemplo, a la moral y a la religión, así como a la educación estética, que en Benjamin son los puntos sobre los que consolidar su sentido reformista.

Ya vimos que el equivalente a nuestro concepto de escuela nueva es a lo que en Alemania se reconocía como "reformismo" o "escuela reformada". También sabemos de los años en que Walter Benjamin estuvo en una escuela reformista en Haubinda y como su impresión fue tal que, al llegar a la Universidad, se decantó por propagar el ideario transformador de G. Wyneken, en un intento de aplicarlo a la propia Universidad, que veía anquilosada, lejos de propiciar una cultura auténticamente juvenil, y más lejos aun, de permitir a los jóvenes estudiantes laborar por encontrar sentido cultural y espiritual a sus vidas de acuerdo a sus sentimientos juveniles. Pues bien, es en este contexto universitario y en el seno de las ideas de Wyneken en donde cabe inscribir los contenidos referentes a las reformas escolares que plantea Benjamin.

Benjamin inicia la cuestión con una afirmación lapidaria tal como que no tenemos una escuela de la verdad, por lo que desde un principio la escuela priva de sus ideales a la juventud (Benjamin, 1913a, 45 y 46), para seguir en otro lugar ampliando estos radicales planteamientos (Benjamin, 1913e, 60 y 61); ya no sólo es la escuela, sino también los padres -en esto la propia experiencia de Walter Benjamin en verdad que estaría presente- desdeñan y no hacen caso a nuestra forma de ser, de tal manera que consideran "retóricos" nuestros pensamientos. Frustrados entonces, la escuela culmina su rol volviendo a los jóvenes indiferentes, al no dejar que los alumnos luchen por el bien -ni por el mal-, sólo por los valores que los adultos consideran positivos.

Por otra parte, está el miedo que se tiene al maestro, ya que él siempre nos malinterpreta, "capta solamente nuestras letras, pero no nuestro espíritu". Como vemos, lo que plantea nuestro autor es una crítica en toda regla a la escuela tradicional así como a la forma tradicional de educar de los padres. Contra ello, sólo restará imponer el espíritu de la pedagogía reformista, una pedagogía que como sabemos se constata en la libertad, libertad que para Benjamin no es un programa, sino una voluntad de realización. Como buen idealista, Benjamin considera la libertad como una idea, como un deseo, es decir, como una mentalidad que debe florecer en los jóvenes a través de la escuela.

Su apoyo a la reforma escolar se implica como defensa de la pedagogía y de los pedagogos frente a los intelectuales diletantes, afirmando que tal reforma es algo que sobrepasa la mentalidad escolar, ya que la reforma va más allá puesto 
que la considera como un verdadero movimiento cultural ${ }^{52}$ (Benjamin, 1912a, 13). Incluso llega a definir el movimiento reformista de la educación como un ideario e incluso como un programa ético, de tal manera que todo movimiento a favor de la nueva educación así como toda crítica al tradicionalismo pedagógico se convierte, ya por ello mismo, en un hecho cultural trascendente e incluso en un verdadero "movimiento" que hace de la crítica un basamento ético.

Ética, porque realmente la reforma de la educación obliga a una revisión axiológica, lo que plantea un tema básico culturalmente hablando ya que tal revisión supone plantear cuáles son los valores que queremos dejar en el futuro, o sea, la reforma escolar como un planteamiento ético-cultural de gran alcance para la conformación de la sociedad del mañana. Pues bien, llegado a este punto, Benjamin afirmara que el lazo que une la reforma de la escuela con la nueva cultura y los nuevos valores no es sino la juventud (Benjamin, 1912a, 16).

Bajo este contexto la escuela aparece como "la institución que custodia y presenta a la humanidad sus adquisiciones" (ibid., 16), con lo que, si creemos en el papel articulante que la juventud juega entre reforma escolar y escuela, será la propia juventud quien aporta el futuro a la escuela, lo que -otro aspecto dialéctico más-, la cultura del futuro deberá ser el verdadero objetivo de la escuela. La conclusión resultará obvia ya que si todo ello es así, entonces, la juventud debe ser la gran protagonista de la escuela, ya que ésta debe dejar actuar al futuro. O sea, no puede haber verdadera educación -educación reformista- sin libertad: "La pedagogía moderna debe crear espacio para la cultura en surgimiento" (ibid.).

Su conclusión es obvia; juventud, nueva escuela y cultura deben formar «El circulus egregius (sic) que en todas y cada una de las direcciones tenemos que recorrer una y otra vez" (ibid.). En definitiva lo que le sorprendió en la escuela de Wyneken: la libertad, la capacidad de decisión del alumno, que, como vemos, era para Benjamin definitorio y nota esencial del reformismo, máxime si contraponemos su experiencia en el Gymnasium, del que decía que no se sabía lo que era la enseñanza humanista (Benjamin, 1913, 2. ${ }^{a}$ parte).

A partir de aquí, los escritos de Benjamin que podemos caracterizar de pedagógicos están enraizados en el contexto universitario, lo que hace que el eje general de su ideología pedagógica lo desarrolle en la Universidad, cuya institución vendría a ser, en estos momentos, sustituta de la escuela. Es decir, para Walter Benjamin, la Universidad no puede estar al margen de la reforma educativa, ya que requiere de todos sus postulados y hallazgos. Éste era uno de los objetivos de la "Asociación de estudiantes libres", a la que Benjamin perteneció desde un

52. A excepción de los institucionistas de la ILE y de sus seguidores, nos sería difícil encontrar entre nosotros un intelectual defensor de la pedagogía y del corpus pedagógico como basamento de cultura. 
principio, y que se configuraba en base a jóvenes descontentos de las organizaciones estudiantiles establecidas, casi todas ellas de marcado carácter político, por lo que, para Benjamin, traicionaban y frustraban la verdadera cultura juvenil, así como los propósitos de la propia juventud, ya que en el fondo estaban establecidas por los adultos como forma de alienación de las verdaderas posibilidades subversivas de la juventud ${ }^{53}$. Lo expresa claramente en otro lugar: "hay que mostrar la rebelión en contra de los padres y en contra de la escuela" (Benjamin, 1913g, 69). O refiriéndose a la Universidad, "lo distintivo en la vida del estudiante es la voluntad de oposición" (Benjamin, 1915, 78).

La conclusión es clara; también es necesaria la reforma de la Universidad, siguiendo los delineamientos del reformismo escolar. De todas formas hay que tener en cuenta que para los estudiantes la reforma escolar era un punto de partida, en el sentido de que no pretendían la intervención en el trabajo pedagógico, no se dirigían hacia la cuestión pedagógica en sí, sino al papel que la juventud tenía que jugar en un seno reformista; es decir, la reforma era el punto de arranque para dilucidar la cuestión estudiantil (Benjamin, 1913f, 64). Nuestro autor era consciente de que la "Asociación", que en su momento llegó a presidir, no era la instancia adecuada para resolver los problemas pedagógicos inherentes al reformismo, de tal manera que no era tarea del estudiante universitario analizar las aportaciones de los reformadores escolares, sino intentar, en un ambiente de reforma, solucionar las problemáticas que les atañían a partir de ellos mismos.

En este trabajo se denota, por primera vez, un cierto distanciamiento de las posturas de Wyneken, aunque no se opta aún por la ruptura, tal como sucedería por su inclinación belicista en 1914; no obstante es aquí cuando Benjamin afirma que no es partidario "fanático" de Gustav Wyneken (ibid.), tal como ya habíamos mencionado, aunque, en parte, aún seguía orientado por su pensamiento. En definitiva, lo que debe buscar la juventud universitaria es encontrarse con su verdadero espíritu y ser fiel al mismo, lo que supondría la creación de una cultura auténtica de la juventud; ahora bien, lo que Benjamin defiende es que esta mentalidad propiamente estudiantil, este renacer de la juventud lo puede aportar la pedagogía reformista (ibid., 67). O como dice el propio Benjamin, la reforma universitaria pretendida debe hacerse "desde dentro hacia fuera" (ibid., 66).

No de forma expeditiva, pero entre líneas, se puede llegar a la conclusión de que esta reforma de la Universidad en base a la cultura juvenil y al desarrollo del verdadero espíritu de la juventud se encuentra en Benjamin en la pedagogía;

53. Acaso "subversivo" no sea el término más adecuado; lo utilizamos para ejemplificar que la cultura juvenil en Walter Benjamin debe ser propia, auténtica, sólo en función del verdadero espíritu juvenil, que es el Espíritu, por no estar contaminado aún por los adultos. Es esta oposición lo que propicia que la juventud deba estar enfrente y frente a los adultos; dentro del discurso dialéctico de Benjamin, la utilización del término "Subversivo" lo consideraríamos una necesidad, o licencia, metodológica. Pedimos disculpas por ello. 
efectivamente, la reforma de la Universidad y, con ello, la implantación de la cultural juvenil, y la transformación que ello implicaría, se encontraría en la reforma pedagógica de la Universidad. La pedagogía entonces como la verdadera piedra de toque de las aspiraciones de los universitarios comprometidos, simplemente porque la nueva pedagogía es a su vez un compromiso con la libertad y, en consecuencia, con el cambio.

Ahora bien, ¿en qué contenidos se debe basar esta pedagogía? Benjamin en sus escritos considera como fundamental la necesidad de transformar la educación estética así como la enseñanza de la moral y de la religión. En consecuencia, una metodología de la aplicación reformista, tanto en la escuela como más tarde en la Universidad, tendría que asentarse en la estética, la moral y la religión. No nos extrañe entonces que la gran mayoría de páginas que sobre la cuestión pedagógica escribiera Walter Benjamin estén dedicadas a estas cuestiones que pretendemos revisar a continuación.

\subsection{La educación estética}

Uno de los trabajos que W. Benjamin escribió estos años sobre pedagogía (vid. Benjamin, 1912b, 16-35) está redactado en forma de diálogo entre él y una persona a la que denomina "filisteo"; es sin duda una pieza curiosa no tanto por el contenido -ciertamente farragoso-, sino por la metáfora que utiliza. ¿Quién es Filisteo? Pues bien, bajo tal denominación encierra el espíritu, la opinión, la forma de ser y de sentir de la burguesía - del adulto burgués- en relación a los valores y a la estética (y también en relación con la religión). En el fondo, no deja de ser una descripción a la vez que un ataque a lo que vio y vivió en el seno de su familia; cabe recordar aquí que entre los múltiples negocios de su padre estaba el de ser corredor de arte, vendedor, tasador, etc., fundamentalmente de pintura ${ }^{54}$; pues bien, el Filisteo es la personificación del pensamiento burgués en relación al arte, o sea, aquel que mira el arte como un objeto, como un valor crematístico, y que, al mismo tiempo, si atesora arte es para evidenciar su capital, y nunca como goce estético, o como valor de la obra en sí misma. Con ello ya podemos intuir cuál era la posición que defendía W. Benjamin, que buscaba el arte en sí, por lo que considera que la escuela debe transmitir como valor educativo no tanto el "arte por

54. Cabe recordar que W. Benjamin, a pesar de todo, siempre se interesó por la cuestión estética y por el arte en general; sus múltiples ensayos sobre literatura (Baudelaire, Kafka, Proust, Calderón de la Barca, Goethe, Valery, la literatura griega, B. Brech, Hördelin... incluso quiso estudiar a Gracián), sobre estética, sus trabajos como crítico de arte en diversas publicaciones así como la investigación que presentó para optar a la cátedra de Filosofía de la Universidad de Fráncfort -El origen del drama barroco alemán (Benjamin, 1990)- son evidencia palpable de nuestra afirmación. Además llegó a coleccionar pintura, tal como se constata en su testamento, que ya citamos. De ello cabe resaltar la adquisición que hizo en 1921 de Angelus Novus, de Paul Klee. 
el arte", que sólo tiene sentido para el artista, sino la esencia del valor estético para despertar el espíritu del alumno.

En cambio en la escuela -en la escuela tradicional se refiere- el arte se utiliza como narcótico, ya que los maestros sumergen a los alumnos en un pasado sin sentido, que sólo se evidencia como recuerdo; con ello el alumno no encuentra el arte sino la castración que le provoca en el resurgir del espíritu, que es y debe ser la verdadera misión de la educación estética (1913b, 47). En el mejor de los casos lo que puede aportar la escuela es un cierto y falso "romanticismo escolar", en el que los poetas como los héroes son sólo bellas figuras oníricas a las que se deben aferrar para así dificultarles el despertar (ibid.). En cambio, lo que tendría que realizar el arte es un romanticismo que fuese a la vez capaz de formar una "voluntad operante", en el sentido de operar hacia el espiritualismo.

Obviamente, el culpable es la comunidad académica a la que "no se le puede disculpar el paganismo, la lejanía al arte como tal" (Benjamin, 1914a, 70); de todas formas la acusación de Benjamin va más lejos, ya que en el fondo lo terrible de la situación es que en la escuela tradicional nada se cuestiona, simplemente se sigue con lo que es habitual, simplemente, porque su gran pecado es "la falta de pensamiento" (ibid.). Con ello, lo máximo que se consigue mediante la educación artística es convertir a los alumnos en "diletantes", es decir, se les educa para ser público, o sea, para aplaudir lo que se debe aplaudir, para que les guste lo que les debe gustar, fuera entonces de todo goce estético personal, propio y espiritual, sin comunión en suma entre el sujeto y el artista ${ }^{55}$.

W. Benjamin (1913, 35-38), en este contexto artístico en el que nos movemos, hace una distinción con pretensiones de funcionalidad entre la aportación educativa que deben realizar la historia y la lengua alemanas; así considera que la lengua debe aportar a la educación los valores estéticos, mientras que la historia debe hacer lo propio con los valores éticos. Además sigue su desarrollo crítico a propósito de la escuela tradicional al afirmar que "la enseñanza no se esfuerza por relacionarse en serio con la obra de arte" (ibid., 37), independientemente de que se obligue a los alumnos a estudiar contenidos que bien podrían denominarse artísticos, aunque sin criterios de ningún tipo, ni tan siquiera sin afán comparativo para que el alumno pudiera extraer conclusiones y sentimientos personales.

Es más, la enseñanza del arte suele iniciarse siempre por orden cronológico, lo que hace que a los estudiantes más jóvenes se les obligue a estudiar -que no a entender- las obras clásicas, que no despiertan ni motivan a los alumnos porque, al estar alejadas de su realidad, no les pueden aportar ningún sentido ni interés. En

55. De nuevo la crítica a la sociedad burguesa de la cual su familia era fiel representante. Téngase en cuenta que para W. Benjamin "diletante" es sinónimo de imitador. O sea, la educación artística convertía al alumno en un imitador de las modas, en un seguidor de corrientes; o sea, la educación artística en las escuelas sirve para educar al público como espectador o consumidor de arte. Vid. p. 72 de Benjamin, W., "Veladas literarias estudiantiles", en Obras, op. cit., libro II, vol. 1. 
cambio de la escuela se suprime el arte moderno, lo que por otra parte dará motivo a una controversia que, si al menos Benjamin no soluciona, la deja inquietantemente planteada; se pregunta hasta qué punto la escuela es responsable respecto de su época. Reflexión que creemos original y que se ha olvidado secularmente. En educación preocupa el pasado -ahí está, por ejemplo, el auge de la Historia de la Educación, como disciplina académica-, preocupa el futuro -para qué sociedad educamos-, pero difícilmente la pedagogía se preocupa por entender que el mundo actual es fruto de proyectos educativos desarrollados previamente.

De ahí que a Benjamin le preocupe el hecho de la responsabilidad de la educación y de la escuela en la conformación de la época actual, ya que, a través de la educación estética, descubre que la escuela, como institución, difícilmente es capaz de asignar valores por sí misma. Lo descubre con el arte en el sentido de que cuando una obra -como el informalismo- deja de refugiarse en las formas y en la representación, cuando el arte se encierra en sí mismo y no asigna valores ${ }^{56}$, la escuela es incapaz por sí misma de valorar y valorarla en sentido axiológico. De ahí que la escuela nunca se haya interesado por el arte moderno.

Pues bien, para nuestro autor, nunca puede haber una educación del espíritu si la escuela abandona uno de los instrumentos más eficaces para ello, ya que el arte encarna como nada ni nadie el desarrollo espiritual que ha logrado un pueblo; a través del arte, el joven puede encontrar los valores que le ayuden a su superación, de tal manera que el humanismo -lo que sería lo divinamente humano- se logra a través del goce estético y de la comprensión del mismo. Sin educación estética difícilmente podrá haber educación, al menos en las coordenadas en que Benjamín la planteaba en sus años de juventud.

\subsection{La educación moral y religiosa}

Obviamente en la tarea del desarrollo espiritual, la moral y la religión son los otros puntales que deben sostener la educación y la formación de la juventud. A tal cuestión dedica uno de sus trabajos más interesantes y, curiosamente, lo realiza de forma monográfica, puesto que, como hemos insinuado, Benjamin siempre fue proclive a tratar muchas temáticas a lo largo de su vida, y también en sus escritos, evidenciando la dificultad para introducir fronteras temáticas al uso. Es también otro rasgo que se encuentra en los trabajos de juventud que estamos analizando, si bien, en la cuestión de la moral, al menos en esta ocasión, rompe con lo que sería una de sus señas de identidad. Efectivamente, en W. Benjamin (1913c, 48-54)

56. A pesar de los años transcurridos, el breve texto de Rubert de Ventós (1963) no ha perdido ni un ápice de su valor a la hora de juzgar el arte abstracto, tanto es así que desde su primera edición se ha ido reeditando en diversas editoriales, la última en Anagrama, en 1997. Para las temáticas del texto interesa sobre todo el tercer capítulo que trata de la objetividad del arte actual. 
encontramos un trabajo monográfico cuyo título, "Enseñaza de la moral", centra la cuestión desde el principio.

En este texto encontramos unos planteamientos que están inspirados por la obra de E. Kant ${ }^{57}$, puesto que, en concreto, afirma que "no resulta posible pensar nada ni en el mundo ni fuera del mundo que podamos considerar bueno sin restricciones, sino tan sólo una voluntad buena" (Benjamin, 1913c, 49). Impuesto el relativismo crítico kantiano pasa a distinguir los contenidos morales de la normatividad moral al afirmar que la verdadera ley moral se asienta en las normas y no en los contenidos morales, de donde se desprende que, efectivamente, la meta de la educación moral debe centrarse en la formación de la voluntad moral, porque la voluntad encierra la capacidad de cumplimentar las normas.

De todas formas W. Benjamin sostiene que la voluntad moral no es una "magnitud psicológica que se pueda tratar", de tal manera que afirma que no hay influencia empírica que garantice el encuentro con la voluntad moral como tal; es decir, y utilizando su expresión, "nos falta la palanca para manejar la educación moral" (ibid.). Por tanto, no está objetivizada la posibilidad moral en el sujeto, por lo que, desde este punto de vista, la conclusión parece ser que cierra el camino formativo, ya que, como viene a afirmar Benjamin, la volunta moral es inaccesible para el educador, porque la ley moral está lejos de lo moral empírico (ibid., 50). Llegado a este punto, Benjamin intenta salvar la posibilidad educativa de la moralidad acogiéndose a su experiencia. Efectivamente, ello significa el recordatorio de sus años en el centro liderado por G. Wyneken.

W. Benjamin nos recuerda que en la "Comunidad escolar libre" el sentido de la moralidad era comunitario -la comunidad era moral- lo que se conseguía mediante el desarrollo de la religiosidad; religiosidad que surgía mediante la experimentación de procesos que despertaban en los jóvenes actitudes religiosas a través de las cuales se configuraba la moral. O sea, que en la práctica escolar de Wyneken, se llegaba a lo moral por experiencias religiosas, con lo que la confusión entre moral y religión se nos aparenta como previsible. La objetividad de la norma se conseguía en la comunidad moral de Haubinda estableciéndola en el nivel de "orden empírico legal", lo que sin duda, y atendiendo a los precedentes vistos, "la vida cotidiana de una comunidad está marcada religiosamente" (ibid., 51). Para que todo ello sea posible, es decir, para que la comunidad moral establezca la normativa moral a través de su legalización empírica, es indispensable la libertad. Sin libertad ni la norma ni su legalidad tendrían valor moral; sólo la libertad es la que permite a lo legal adaptarse a la norma y ser considerada como moral por la comunidad. Sin libertad no puede haber norma legal moral.

57. En concreto vid. Kant (1921). En 1946 apareció publicada la misma edición por Espasa Calpe, en su colección Austral. Consideramos que es la mejor versión en castellano, gracias a la fidelidad de su traductor, Manuel García Morente, con la versión original. En 1996, la editorial Ariel de Barcelona publicó la última de las versiones que conocemos. 
En consecuencia, y como nos dice taxativamente nuestro autor, "el mayor peligro de la enseñanza de la moral radica en la motivación y legalización de la voluntad pura, es decir, de la opresión de la libertad" (ibid., 51), o lo que es lo mismo, la normatividad moral no debe imponerse jamás; lo que nos lleva a plantear otra cuestión no menos interesante, a saber, si no puede imponerse, si se coacciona la libertad, la moral no puede enseñarse asignándole el papel de meta u objetivo, pues si la enseñaza de la moral se concibe de esta forma, todo el proceso formativo se encuentra dirigido y, por tanto, carente de libertad para que el comportamiento alcance verdadera categoría moral.

Libertad y religiosidad son pues los puntales básicos del pensamiento de W. Benjamin en estas cuestiones, ya que, como afirma, los contenidos concretos de la norma vienen determinados por la religiosidad del individuo. Sin embargo, lo que se suele hacer es llevar a cabo un extraño tipo de educación cívico-moral a través de ejemplos de personas y actuaciones a los que se les presupone moralidad, cuando sabemos que los ejemplos morales sirven en todo caso como modelos, pero no nos aportan el concepto de moralidad ${ }^{5}$. En todo caso, los ejemplos y modelos morales sólo pueden experimentarse en la realidad vital, es decir, en la comunidad de estudiantes, pero nunca como un elemento propio de la enseñanza de la moral (ibid., 52).

Se llega pues a la conclusión de que la enseñanza de la moral no dispone de motivaciones auténticamente morales para tal enseñanza, lo que hace que se tenga, por parte de los profesores, "falta de escrúpulos" -como dice Benjamin- a la hora de elegir los medios para llevarla a cabo. En este sentido, ni las reflexiones racionalistas ni los análisis intelectuales ni los estímulos psicológicos ni aspectos tales como la exigencia, el sacrificio, el heroísmo o lo extraordinario aportan nada a la formación de una "mentalidad moral"; en todo caso, lo máximo que pueden lograr es la "exaltación sentimental" (ibid., 52).

Llegado a este punto, el pensamiento de Benjamin -no vamos a negarlo- se va diluyendo poco a poco, ante ciertas dificultades para encontrar una explicación clara de lo que fuere su tesis al principio de su escrito -la moral en comunidad-. Cita a F. W. Foerster y su Teoría de la juventud ${ }^{9}$ para insistir en la falacia de la moralidad psicológica. Por lo demás, vuelve a insistir en que la enseñanza de la moral está aún lejos de satisfacer una exigencia pedagógica; aconseja en todo caso que la educación de la moralidad abandone lo periférico y lo anecdótico para ir desentrañando el "espíritu objetivo" (ibid., 53). Como se ve, W. Benjamin vuelve de nuevo a sus orígenes y a sus motivaciones primigenias, la juventud, el espíritu y la cultura, de tal manera que concluye afirmando «en este sentido hay que tener la esperanza

58. De nuevo influencia kantiana manifestada ya en ibid.

59. De este autor sólo conocemos dos obras en castellano; vid. Foerster (1935 y 1965). Asimismo prologó la monumental obra de De Hovre (1946). Sobre este autor puede consultarse Berchem (1973). 
de que la enseñanza de la moral represente la transición a una nueva enseñaza de la historia en la que también el presente encuentra su lugar dentro de la historia de la cultura" (ibid., 54.) Afirmación cogida un poco a contrapelo y que se aleja de los objetivos por los cuales escribió el artículo. O no, acaso la "enseñanza de la moral" era la excusa para refrendar la necesidad de la nueva cultura en la juventud, que era, no se olvide, su anhelo por aquellos años.

En otro lugar, intenta una aproximación a la religiosidad de la juventud (Benjamin, 1914c, 74-76), afirmando que ésta, por lo general, se encuentra alejada de las posiciones religiosas, aunque también nos dice que comienza a adquirir un cierto significado en muchos jóvenes de tal manera que dejándose llevar por el optimismo escribe que "la ayuda de Dios le está muy próxima" (ibid., 75). De todas formas vuelve a criticar al tradicionalismo escolar pues manifiesta que la juventud, en referencia a la religión, se encuentra muy desorientada, pues actúa de acuerdo con las palabras propias de un maestro de escuela, es decir, en función de lo que está "permitido" y de lo que está "prohibido" y, efectivamente, esto no conforma una educación religiosa, ya que en todo caso sería la culpable de la lejanía de la juventud respecto de la religión. ¿La solución? Una vez más la educación en libertad, o sea, la escuela reformada y reformadora, ya que sólo a través de la elección el sujeto crea su moral, aproximándose de esta forma al espíritu de la religión.

Sólo un inciso para clarificar alguna cuestión personal de Walter Benjamin, en relación a la religión. Siendo fiel a su idea rectora -espiritualidad, cultura, juventud- el joven Benjamin, si bien interesado por el papel de la moral y de la religión, como configuradoras, junto con la sensibilidad estética, de la espiritualidad y del humanismo, había dejado ya de ser creyente. Esto no significa que fuese ajeno e insensible al problema judío; tenemos en este sentido un documento que creemos que es interesante para dilucidar tal cuestión; resulta que ante las mofas y burlas que ya se producían en la Universidad alemana, en 1913, en contra de los alumnos judíos, incluso en el seno de la "Asociación de estudiantes libres" a la que Walter Benjamin pertenecía, y siendo judío como bien se sabe, afirmaba que "mientras una de tales personas tenga sitio entre los jóvenes alemanes libres, careceremos de juventud y nobleza». Por otra parte, su negación del sionismo era una actitud coherente con su pertenencia a una asociación estudiantil que no aceptaba en su seno ningún tipo de corriente política.

Por esto mismo, y confirmando lo mencionado, es decir, su agnosticismo y su lejanía sionista, ya a partir de 1912 consideraba el judaísmo (aunque sin citarlo expresamente, bajo la denominación genérica "religión", referida a cualquiera de ellas) (Benjamin, 1912b, 26 y ss.) y despojaba la actitud hebrea lejos de cualquier matiz político o nacionalista. Benjamin siempre consideró, a lo largo de su vida, al sionismo como un bien cultural -otra de las herencias permanentes originaria de los años que estudiamos-; ahora bien, no un bien cultural encerrado en sí mismo sino como un bien cultural exógeno, que podía sin duda coadyuvar al desarrollo y al enriquecimiento de la cultura europea, simplemente porque en el sionismo 
también se podían encontrar las representaciones más elevadas del espíritu ${ }^{60}$, incluso en tonos mayores al propio cristianismo.

\subsection{El sexo}

Casi como curiosidad traemos a estas páginas algunas, escasas, opiniones que el joven Walter Benjamin dejó caer en sus escritos educativos sobre la cuestión sexual, tema que como se comprenderá interesaba y ha interesado siempre a los jóvenes. En general son escritos marginales o referencias escuetas que realiza al pairo de otras temáticas.

El contexto de las afirmaciones que realiza a propósito de la cuestión sexual es el propio de los planteamientos ideológicos que en la época poseía W. Benjamin; es decir, la cuestión sexual en los jóvenes está mediatizada por los adultos como una forma de opresión más de aquéllos. La juventud sigue en manos de la cultura senil de sus mayores - de ahí la necesidad de una cultura propia, en donde todas las cuestiones tendrían una solución juvenil, incontaminada- ya que los modelos sexuales que el joven reconoce son propios de la opresión familiar que lo desvirtúa (1914b) o de las prostitutas -el erotismo de las prostitutas, tal como afirma, y que así y todo, considera más próximo a los jóvenes (1914b, 74), pero que en el fondo pertenece al mundo de la cultura erótica del adulto-.

El joven, como tal, no es adulto, y nada tiene que ver con la cultura adulta, y menos aun en algo que es tan propio y personal como la cuestión sexual; sin embargo y a pesar de ello, también se deja llevar por las "costumbres seniles y perversas" de los adultos que lo incitan hacia la prostitución y los cabarés ya que son las únicas salidas sexuales que se encuentran a su disposición (Benjamin, 1913a, 45); es decir, una vez más, se evidencia que en cuestiones donde el joven tendría que ser autónomo se deja nuevamente avasallar por la represión patriarcal. Una vez más la juventud se manifiesta como una minoría oprimida en las fiestas de los adultos (ibid.).

Un escrito de W. Benjamin (1913), reproducido incluso dando título a un libro recopilatorio (Benjamin, 1993), se refiere ampliamente a la temática de la prostitución y al papel de las putas. Sin embargo, si lo traemos a colación es más por ser un escrito de sus años de juventud aunque apenas se desprende de él interés pedagógico. En este texto, a pesar de su cabecera La metafísica de la juventud, se refiere más al tema de la comunicación que no a otra cosa, "la conversación tiende al silencio, y el oyente es más bien el que se calla. El hablante recibe de él

60. En el libro inconcluso de Los pasajes (Benjamin, 2006a), en donde pretendía, aplicando el materialismo histórico, historiar el París del siglo XIX, se intuye que estaba a favor de realizar una obra judía en Europa y no en Palestina. Acaso por esta determinación siempre se negó a trasladarse a Jerusalén tal como había hecho su amigo Gershom Scholem, que nunca se cansó de aconsejarle que se estableciese en tal ciudad. La correspondencia entre ambos testifica sin lugar a dudas lo afirmado. 
sentido; el silente es la fuente del sentido que se halla por captar" (p. 94), para concluir con algunos pensamientos próximos al existencialismo, "pero el genio que habla es más silencioso que el oyente, igual que quien reza es más silencioso que Dios mismo" (p. 95) ${ }^{61}$. Todo ello para dar a entender que el uso de la prostitución por parte del hombre no deja de ser una necesidad expresiva por parte de éste que sin embargo nunca culmina con satisfacción. El hombre debe confiar sus confidencias -tiene presente-, en cambio la puta sólo tiene pasado; su escuchar es el silencio, pero escucha el silencio de la pequeñez de su cliente puesto que la grandeza se les escapa a ambos de tal manera que es sólo en la lujuria en donde se encuentra la conversación del silencio. O como dice el mismo W. Benjamin: «El silencio de la conversación era lujuria futura; mientras que la lujuria era el silencio pasado" (p. 98).

Acaso otro aspecto interesante de este texto se encuentra en el diálogo que mantiene la puta con un Genio -en el sentido de figura fabulosa y mítica- en el que se manifiestan algunos aspectos próximos a las teorías freudianas tanto de sexo como del tanatos; en un momento dado el Genio le dice a la prostituta: "Sólo pienso en mi madre. ¿Puedo hablarte de ella? Ella me parió... mi madre siempre me miraba. He olvidado en ella a toda la gente. Todos se convirtieron en mi madre. Todas las mujeres me habían parido, pero ningún hombre me había engendrado". La puta le contesta: "Así se lamentan cuantos duermen conmigo. Cuando están mirando conmigo en su vida, sienten que se eriza hasta el cuello, como ceniza espesa. Nadie los ha engendrado y a mí acuden para no engendrar". Más adelante el Genio afirma que le han parido muerto, a lo que la prostituta poniendo fin al diálogo le contesta que es ella la más osada con la muerte (pp. 96 y 97).

Estamos entonces ante el vacío y la nada de la experiencia de la prostitución por parte de una juventud que por lo general sólo podía superar su frustración sexual de esta manera y por supuesto ante la queja de que los jóvenes en la sociedad en la que viven no pueden desarrollar el eros en el seno de una cultura juvenil que no se les permite instalar y que sólo les ofrece la sordidez de las costumbres adultas.

Hay que tener en cuenta que, por la época de estos escritos, un grupo de ambos sexos de estudiantes universitarios, tal como ya mencionamos, alquilaron un piso para llevar a cabo en él sus tertulias literarias y culturales que tenían que

61. Ya sabemos que no hay relación con la teoría de la comunicación de SARTRE (1961). Sin embargo, el joven W. Benjamin ya intuye la futilidad del diálogo y el papel que el otro juega para el hablante. Simplemente hemos querido aportar esta reflexión por si en algún momento se quiere analizar el sentido existencial de esta época de nuestro autor, aunque no cabe duda de que como se distingue en filosofía estaríamos más ante una postura existenciaria, intuitiva, que no ante reflexiones propias de la filosofía existencialista. Siempre se ha dicho que M. de Unamuno y S. Kierkegaard -sobre todo el de su Diario íntimo (1955) - son los autores más representativos del existenciarismo, si es que se nos permite el uso de tal anómala expresión. Decir que el título original de la obra citada de S. Kierkegaard, en danés, era simplemente Journal. 
ser foco de la recreación de una cultura verdaderamente juvenil. Pues bien, una de las ventajas de lo que denominaban "El hogar" era poseer un espacio de libertad, de independencia respecto de los adultos, y en donde creemos que las relaciones entre los estudiantes de distinto sexo serían más libres y, en consecuencia, con una sexualidad descontaminada de los mores de los adultos. En aquellos años, y durante bastante tiempo, Benjamin había iniciado un noviazgo con Grete Rad ${ }^{62}$.

\section{A MODO DE CIERRE: LA CRÍTICA Y EL SENTIDO CRÍTICO}

Hemos intentado clarificar, en la medida de lo posible, la posición que ante la pedagogía presenta Walter Benjamin así como su pensamiento educativo, siempre en confusión con sus anhelos juveniles en torno a la necesidad de lograr una cultura juvenil que sería la manifestación y el contexto en donde se desarrollaría el espíritu de la juventud. Pues bien, dentro de tal contexto, hemos ido descubriendo algunos aspectos que formarán parte de la obra futura de nuestro autor, por lo que nos reafirmamos en el hecho de que sus escritos pedagógicos de juventud nos sirven para mostrar la génesis de parte, importante creemos, de su pensamiento adulto. Séanos permitida pues una mera revisión.

a) En primer lugar cabe denotar un cierto determinismo de su biografía escolar a lo largo de su vida, que, una vez intelectualizada, da salida a su ideario pedagógico, primero, y luego, más tarde, a los recuerdos de su niñez, así como una sorprendente e interesante atención respecto de la infancia.

b) Debido a la problemática escolar y familiar, aparece, como mecanismo de defensa, su cerrazón en sí mismo, su arraigada individualidad, que fue tan característica a lo largo de su vida y de su obra, en verdad personal e individualista como pocas. De ahí la necesidad acuciante que sentía a veces de compañía y también sus enamoramientos continuados; también sus inseguridades y en parte su suicidio ${ }^{63}$ y el previo intento en Niza, tras una de sus estancias en Ibiza.

62. Vid. WitTe (2002, 33 y 39). Según este autor Grete estudiaba en Múnich, por lo que considera que fue éste el motivo de su cambio de Universidad en 1915. Indudablemente es una razón de peso, aunque esta decisión no la tomó en años anteriores. Creemos que su fracaso al frente de la "Asociación de estudiantes libres" de la Universidad de Berlín fue también un motivo decisorio para seguir sus estudios en la capital de Baviera.

63. Walter Benjamin se suicidó con una fuerte dosis de morfina en pastillas en la habitación del Hotel de Francia en Port Bou (Cataluña), después de que la policía española no le dejase proseguir por España y anunciarle que al día siguiente sería deportado a Francia. Con un visado absolutamente legal, que le había conseguido Th. Adorno desde los Estados Unidos, la pretensión de Benjamin era trasladarse a Portugal y de allí embarcarse a Nueva York y, luego, muy posiblemente, a La Habana, donde el mismo Adorno le había encontrado trabajo como profesor de su Universidad. El miedo al nazismo, a ser 
c) Encontramos también el origen de sus contradicciones y tránsitos tan comunes en su obra y en su personalidad. Tanto Walter Benjamin, como su obra, además de poliédrica es asaz dicotómica, con ciertas ambigüedades reflexivas. De hecho los puntos y apartes de su vida también se encuentran reflejados en su escritura y en su obra.

d) Otra correspondencia es su interés manifiesto por la educación estética y su dedicación profesional como crítico de arte, principalmente literatura y pintura.

e) También intuimos en sus primeros escritos su tendencia a la complejidad, a la amalgama de ideas, que harán que su obra sea ciertamente de lectura dificultosa.

f) El origen de su agnosticismo que hará que considere el sionismo en su vertiente cultural y en absoluto como sinónimo de política nacionalista. De todas formas parece ser que consideró la cultura judía, que ciertamente conocía, superior a la cristiana; incluso en algún momento de su vida se afanó en estudiar hebreo.

Ahora bien, la gran aportación de estos escritos pedagógicos a la hora de vislumbrar los orígenes de su pensamiento y de su obra, más que los puntos indicados, la encontramos en el sentido crítico que luego será la gran constante de su obra. El propio Walter Benjamin se consideró antes crítico que ensayista o filósofo, de tal manera que si hay un concepto, una palabra, que de alguna forma valga para definir su obra es exactamente ésta: "crítica".

En casi todos los trabajos pedagógicos analizados hace gala de la crítica como forma de racionalización; crítica a la Universidad, crítica a la pedagogía tradicional, crítica a los valores sociales (encarnados por los adultos); incluso en uno de esos primigenios escritos que hemos analizado (Benjamin, 1915) afirma que "lo distintivo en la vida del estudiante es la voluntad de oposición" (p. 78), o también "la sumisión sin crítica ni resistencia es un rasgo esencial de la actual vida estudiantil” (p. 79).

En Benjamin, la crítica actúa como metodología intelectual y como exposición reflexiva, si bien es algo más que todo esto; para Walter Benjamin es y será siempre fuente de conocimiento, manteniendo desde esta perspectiva actualizado su

\footnotetext{
devuelto y entregado a las autoridades alemanas, el recuerdo de su hermano brutalmente torturado y asesinado en un campo de concentración, el cansancio por las largas caminatas por los Pirineos -por la ruta Lister-, su cada vez más acuciante enfermedad coronaria, que hizo que a duras penas pudiese llegar a la frontera, la ansiedad y el nerviosismo propio de la huida, así como algunos componentes de su personalidad en estado límite, le hicieron tomar la fatídica pero comprensible decisión. Lo triste del caso es que el resto de expedicionarios que le acompañaban y a los que tampoco se les permitió proseguir en su entrada a España no tuvieron al día siguiente ninguna dificultad en hacerlo. Acaso el fallecimiento de Benjamin hizo reconsiderar a las autoridades españolas su decisión del día anterior. Decir, por otra parte, que ya antes de sus estancias en Ibiza, W. Benjamin había experimentado con diversos tipos de drogas. Para alguna de esas experiencia vid. Benjamin (1995, primera edición de 1973).
} 
conocimiento de Hegel. Nuestro autor manifestó siempre facilidad para afiliarse a la crítica como ejercicio intelectual, puesto que desde estos sus primeros escritos la aplicó a través de la dialéctica hegeliana, lo que a su vez le facilitó su afiliación a la teoría crítica marxista y, por ende, a la Escuela de Fráncfort. Por último, no podemos olvidar que en sus escritos, cuando se refiere a la crítica a la escuela tradicional, considera tal crítica con categoría de basamento ético.

Por todo lo visto, creemos que en estos escritos se descubren ya algunos de los puntos de inflexión más importantes de lo que luego será su voluminosa obra. Así pues, para iniciarse en ella y para aprender a leer a Walter Benjamin, estos primeros escritos se nos presentan como cruciales. La pedagogía quizás no formó una parte importante y significativa de su obra, sin embargo, en ella está la verdadera pedagogía que nos puede facilitar la compleja lectura de W. Benjamin.

\section{REFERENCIAS BIBLIOGRÁFICAS}

Benjamin, W. (1911) La bella durmiente, en Benjamin, W. (2007) Obras, libro iI, vol. 1. Madrid, Abada.

- (1912a) La reforma escolar, un movimiento cultural, en Benjamin, W. (2007) Obras, libro II, vol. 1. Madrid, Abada.

- (1912b) Diálogo sobre la religiosidad del presente, en Benjamin, W. (2007) Obras, libro II, vol. 1. Madrid, Abada.

- (1913) Enseñanza y valoración, en Benjamin, W. (2007) Obras, libro II, vol. 1. Madrid, Abada.

- (1913a) Romanticismo. Un discurso no pronunciado ante la juventud escolar, en Benjamin, W. (2007) Obras, libro II, vol. 1. Madrid, Abada.

- (1913b) Romanticismo: la respuesta del profano, en Benjamin, W. (2007) Obras, libro II, vol. 1. Madrid, Abada.

- (1913c) La enseñanza de la moral, en Benjamin, W. (2007) Obras, libro iı, vol. 1. Madrid, Abada.

- (1913d) Experiencia, en Benjamin, W. (2007) Obras, libro II, vol. 1. Madrid, Abada.

- (1913e) Pensamientos sobre el "Festival" de Gerhart Hauptmann, en Benjamin, W. (2007) Obras, libro II, vol. 1. Madrid, Abada.

- (1913f) Metas y caminos de los grupos pedagógicos estudiantiles en las universidades alemanas (con especial referencia a la "corriente de Friburgo"), en Benjamin, W. (2007) Obras, libro II, vol. 1. Madrid, Abada.

- (1913g) La juventud se mantuvo en silencio, en Benjamin, W. (2007) Obras, libro II, vol. 1. Madrid, Abada.

- (1913-1914) Metafísica de la juventud, en Benjamin, W. (2007) Obras, libro II, vol. 1. Madrid, Abada. 
JUVENTUD Y PEDAGOGÍA (SOBRE LA GÉNESIS DEL PENSAMIENTO DE WALTER BENJAMIN)

- (1914a) Veladas literarias estudiantiles, en Benjamin, W. (2007) Obras, libro II, vol. 1. Madrid, Abada.

- (1914b) Educación erótica, en Benjamin, W (2007) Obras, libro II, vol. 1. Madrid, Abada.

- (1914c) La posición religiosa de la nueva juventud, en Benjamin, W. (2007) Obras, libro II, vol. 1. Madrid, Abada.

- (1915) La vida de los estudiantes, en Benjamin, W. (2007) Obras, libro iI, vol. 1. Madrid, Abada.

- (1971) Angelus Novus. Barcelona, Edhasa.

- (1975-1985) Geseammelte Schriften (12 vols. integrados en 6 tomos). Fráncfort, Surhrkamp Verlag.

- (1972-1995) Iluminaciones I, II, III y IV. Madrid, Taurus.

- (1987a) Infancia en Berlín hacia 1900. Madrid, Alfaguara.

- (1987b) El Berlín demoniaco. Barcelona, Icaria.

- (1988a) El concepto de crítica de arte en el romanticismo alemán. Barcelona, Península.

- (1988b) Diario de Moscú. Madrid, Taurus.

- (1989) Escritos. Buenos Aires, Nueva Visión.

- (1990) El origen del drama barroco alemán. Madrid, Taurus.

- (1991a) Agesilaus Santander. Revista Nadja, n. 3.

- (1991b) El Narrador, en Para una crítica de la violencia y otros ensayos. Madrid, Taurus.

- (1993) La metafísica de la juventud. Barcelona. Paidós/Ice de la UAB.

- (1995) Haschisch. Madrid, Taurus.

- (1996a) Escritos autobiográficos. Madrid, Alianza.

- (1996b) España 1932, en Benjamin, W. Escritos autobiográficos. Madrid, Alianza.

- (1996-2002) Selected Writings. Cambridge (Mass.), Harvard University press.

- (1999a) Program for a Proletarian Children's Theater, en Selected Writings, vol. 2, part. 1 (1927-1930). Cambridge (Mass.), Harvard University press, 202-205.

- (1999b) Agesilaus Santander, en Diario de Poesía, n. 5.

- (2004a) Agesilaus Santander, en Scholem, G. Los nombres secretos de Walter Benjamin. Madrid, Trotta, 59-64.

- (2004b) Sobre la fotografía. Valencia, Pre-textos.

- (2006a) Pasajes. Madrid, Akal.

- (2006b) La obra de arte en la época de su reproductibilidad técnica, en Obras, libro I, vol. 1. Madrid, Abada.

- (2006-2010) Obras. Madrid, Abada.

- (2008a) Cartas de la época de Ibiza. Valencia, Pre-textos.

- (2008b) Papeles escogidos. Buenos Aires, Imago Mundi.

- (2009a) Teatro y radio. Sobre el control recíproco de lo que es su trabajo educativo, en Benjamin, W. Obras, libro iI, vol. 2. Madrid, Abada, 389-393.

- (2009b) Franz Kafka. Construyendo la muralla china, en Obras, libro II, vol. 2. Madrid, Abada. 
- (2009c) La situación del arte cinematográfico en Rusia, en Obras, libro II, vol. 2. Madrid, Abada.

- (2009d) Sobre la situación social que el escritor francés ocupa actualmente, en Obras, libro II, vol. 2. Madrid, Abada.

Benjamin, W. y Adorno, T. (1998) Correspondencia, 1928-1940. Madrid, Trotta.

CANO, R. (2000) El pasajero Walter Benjamin. Tarragona, Ígitur (narrativa).

De Hovre, F. (1946) Pedagogos y Pedagogía del Catolicismo. Madrid, Editorial Fax.

Fitche, J. G. (1988) Discursos a la nación alemana. Madrid, Tecnos.

Foerster, F. V. (1935) Ética de la Juventud. Barcelona, Labor.

- (1946) Prólogo a De Hovre, F. Pedagogos y pedagogía del catolicismo. Madrid, Editorial Fax.

- (1965) Ética y pedagogía sexual. Alcoy, Marfil.

Goodman, P. (1970) La Comunidad de los Estudiantes. Buenos Aires, Ed. Proyección.

- (1974) La deseducación obligatoria. Barcelona, Península.

- (1975) Problemas de la Juventud en la Sociedad Organizada. Barcelona, Península.

- (1976) La nueva reforma. Barcelona, Kairós.

JARQUE, V. (1992) Imagen y metáfora. La estética de Walter Benjamin. Cuenca, Ediciones de la Universidad de Castilla-La Mancha.

Kant, E. (1921) La Metafísica de las costumbres. Madrid, Colección Universal de Espasa Calpe.

Kierkegaard, S. (1955) Diario intimo. Buenos Aires, Santiago Rueda, editor.

LANE, R. J. (2005) Walter Benjamin: Writing Through the Catastrophe. Manchester y Nueva York, University press.

LesKov, N. (2003) Lady Macbeth de Mtsensk y otros relatos. Madrid, Alba.

Löwith, K. (2008) Nietzsche. La quiebra revolucionaria del pensamiento del siglo XIX. Buenos Aires, Katz ed.

Luzuriaga, L. (1929) Las escuelas nuevas alemanas. Madrid, Publ. de la Rev. de Pedagogía.

Marcuse, H. (1969) El final de la utopía. México, Siglo xxi.

Missac, P. (1997) Walter Benjamin, de un siglo a otro. Barcelona, Gedisa.

Muñoz, J. (1998) Introducción a Theodor Adorno-Walter Benjamin. Correspondencia, 1928-1940. Madrid, Trotta.

Musil, R. (2002) Las tribulaciones del estudiante Törless. Barcelona, Seix Barral.

Revista de Ciencias Sociales (2003), monográfico sobre W. Benjamin.

RickerT, H. (1945) Ciencia cultural y ciencia natural. Madrid, Espasa-Calpe, colec. Austral.

Rubert De Ventós, X. (1997) El arte ensimismado. Madrid, Anagrama.

SAFRANSKI, R (2006) Schiller o la invención del idealismo alemán. Barcelona, Tusquets editores.

SCHiller, F. (1990) Cartas sobre la educación estética del hombre. Barcelona, Anthropos.

Scholem, G. (1981) Walter Benjamin. Histoire d'une amitié. París, Calmann-Levy. 
JUVENTUD Y PEDAGOGÍA (SOBRE LA GÉNESIS DEL PENSAMIENTO DE WALTER BENJAMIN)

- (ed.) (1987) Walter Benjamin/Gershom Scholem. Correspondencia (1933-1940). Madrid, Taurus.

- (2004) Los nombres secretos de Walter Benjamin. Madrid, Trotta.

SElz, J. (1954) Walter Benjamin à Ibiza, en Les lettres nouvelles.

Shelling, F. (1984) Lecciones sobre el método de los estudios académicos. Madrid, Editora Nacional.

Stewart, E. (2010) Catastrophe and Survival: Walter Benjamin and Psychoanalysis. Nueva York y Londres, Continuum Publ. corp.

Tiedemann, R.; Gödde, C. y Lonitz, H. (1990) Walter Benjamin 1892-1940. Marbacher Magazine, n. ${ }^{\circ} 55$.

Valero, V. (2001) Experiencia y pobreza. Barcelona, Península.

Van Berchem, A. (1973) FW Foerster. Celigny, Éditions Nant de Pry.

Wiтtте, B. (2002) Walter Benjamin. Una biografia. Barcelona, Gedisa.

Wolin, R. (2002) Walter Benjamin, an aesthetic of redemption. Nueva York, Columbia University press.

Wyneken, G. (1926) Las comunidades escolares libres. Revista de Pedagogía, n. 59 de noviembre, 507-511.

- (1927a) La escuela y la cultura juvenil. Revista de Pedagogía, n. ${ }^{\circ}$ 69, septiembre, 409-413.

- (1927b) Escuela y cultura juvenil, 2 vols. Madrid, La Lectura-Espasa Calpe. 